\title{
Mechanisms of microbial carbon sequestration in the ocean - future research directions
}

\author{
N. Jiao ${ }^{1}$, C. Robinson ${ }^{2}$, F. Azam ${ }^{3}$, H. Thomas ${ }^{4}$, F. Baltar ${ }^{5}$, H. Dang ${ }^{1}$, N. J. Hardman-Mountford ${ }^{6}$, M. Johnson ${ }^{2}$, \\ D. L. Kirchman ${ }^{7}$, B. P. Koch ${ }^{8}$, L. Legendre ${ }^{9,10}$, C. Li ${ }^{11}$, J. Liu ${ }^{1}$, T. Luo ${ }^{1}$, Y.-W. Luo ${ }^{1}$, A. Mitra ${ }^{12}$, A. Romanou ${ }^{13}$, \\ K. Tang ${ }^{1}$, X. Wang ${ }^{14}$, C. Zhang ${ }^{15}$, and R. Zhang ${ }^{1}$ \\ ${ }^{1}$ State Key Laboratory of Marine Environmental Science, Xiamen University, Xiamen 361005, China \\ ${ }^{2}$ School of Environmental Sciences, University of East Anglia, Norwich Research Park, Norwich, UK \\ ${ }^{3}$ Scripps Institution of Oceanography, UCSD, La Jolla, CA 920193, USA \\ ${ }^{4}$ Dalhousie University, Halifax, Nova Scotia, Canada \\ ${ }^{5}$ Department of Marine Science, University of Otago, P.O. Box 56, Dunedin 9054, New Zealand \\ ${ }^{6}$ CSIRO Marine and Atmospheric Research, Floreat, WA 6014, Australia \\ ${ }^{7}$ School of Marine Science and Policy, University of Delaware, DE 19958, USA \\ ${ }^{8}$ Alfred-Wegener-Institut Helmholtz-Zentrum für Polar- und Meeresforschung, 27570 Bremerhaven, Germany \\ ${ }^{9}$ Sorbonne Universités, UPMC Univ. Paris 06, UMR7093, Laboratoire d'Océanographie de Villefranche, \\ 06230 Villefranche-sur-Mer, France \\ ${ }^{10}$ CNRS, UMR7093, Laboratoire d'Océanographie de Villefranche, 06230 Villefranche-sur-Mer, France \\ ${ }^{11}$ Chinese University of Geology, Wuhan, China \\ ${ }^{12}$ Centre for Sustainable Aquatic Research, Swansea University, Swansea, UK \\ ${ }^{13}$ Dept. of Applied Physics and Applied Math., Columbia University and NASA-Goddard Institute for Space Studies, \\ 2880 Broadway, New York, NY 10025, USA \\ ${ }^{14}$ South China Sea Institute of Oceanology, Chinese Academy of Sciences, Guangzhou, China \\ ${ }^{15}$ Tongji University, Shanghai, China \\ Correspondence to: N. Jiao (jiao@xmu.edu.cn), C. Robinson (carol.robinson@uea.ac.uk), \\ F. Azam (fazam@ucsd.edu), and H. Thomas (helmuth.thomas@dal.ca)
}

Received: 8 May 2014 - Published in Biogeosciences Discuss.: 3 June 2014

Revised: 27 August 2014 - Accepted: 27 August 2014 - Published: 1 October 2014

\begin{abstract}
This paper reviews progress on understanding biological carbon sequestration in the ocean with special reference to the microbial formation and transformation of recalcitrant dissolved organic carbon (RDOC), the microbial carbon pump (MCP). We propose that RDOC is a concept with a wide continuum of recalcitrance. Most RDOC compounds maintain their levels of recalcitrance only in a specific environmental context $\left(\mathrm{RDOC}_{\mathrm{t}}\right)$. The ocean RDOC pool also contains compounds that may be inaccessible to microbes due to their extremely low concentration $\left(\mathrm{RDOC}_{\mathrm{c}}\right)$. This differentiation allows us to appreciate the linkage between microbial source and RDOC composition on a range of temporal and spatial scales.
\end{abstract}

Analyses of biomarkers and isotopic records show intensive MCP processes in the Proterozoic oceans when the MCP could have played a significant role in regulating climate. Understanding the dynamics of the MCP in conjunction with the better constrained biological pump (BP) over geological timescales could help to predict future climate trends. Integration of the MCP and the BP will require new research approaches and opportunities. Major goals include understanding the interactions between particulate organic carbon (POC) and RDOC that contribute to sequestration efficiency, and the concurrent determination of the chemical composition of organic carbon, microbial community composition and enzymatic activity. Molecular biomarkers and isotopic tracers should be employed to link water column processes 
to sediment records, as well as to link present-day observations to paleo-evolution. Ecosystem models need to be developed based on empirical relationships derived from bioassay experiments and field investigations in order to predict the dynamics of carbon cycling along the stability continuum of POC and RDOC under potential global change scenarios. We propose that inorganic nutrient input to coastal waters may reduce the capacity for carbon sequestration as RDOC. The nutrient regime enabling maximum carbon storage from combined POC flux and RDOC formation should therefore be sought.

\section{Introduction}

The ocean absorbs approximately $30 \%$ of anthropogenic $\mathrm{CO}_{2}$ (IPCC, 2013), mitigating global warming in a profound way. However, the biological mechanisms for long-term carbon sequestration in the ocean are not fully understood. The biological pump (BP) is the collective term for a suite of processes by which carbon dioxide that is fixed by phytoplankton photosynthesis in the euphotic zone is exported to the deep ocean. These processes include the passive flux of sinking organic particles (dead cells, faecal pellets, etc.), the active flux of dissolved and particulate organic material mediated by vertical migration of zooplankton, and the vertical transport of dissolved organic material by physical processes. Around $50 \%$ of the photosynthetically produced particulate organic carbon (POC) is transformed through mechanisms including excretion, zooplankton grazing, viral lysis and the action of microbial ectohydrolases into dissolved organic carbon (DOC) (Anderson and Tang, 2010). The production rate and chemical composition of this dissolved organic matter (DOM) is influenced by the nutrient status and community composition of the microbial food web. Operationally DOC is defined as all compounds less than $0.2 \mu \mathrm{m}$ in size (Carlson et al., 2002), and thus will include microparticulates (e.g., cell wall fragments, membranes, viruses etc.) and metabolites leaked/released by photo-autotrophs, defecated by phagoheterotrophs and associated with viral lysis of host cells. Marine microbes readily utilize most of this DOC, producing $\mathrm{CO}_{2}$ and in turn transforming the composition of the DOM. However, an estimated $\sim 5-7 \%$ of the microbially produced DOC is recalcitrant (RDOC) and resists rapid remineralization (Ogawa et al., 2001; Gruber et al., 2006; Koch et al., 2014), which enables the DOC to be exported below the seasonal thermocline and sequestered in the oceans' interior.

The microbial carbon pump (MCP) (Jiao et al., 2010a) describes the ecological processes and chemical mechanisms that produce RDOC throughout the water column. The resilience of RDOC to degradation by marine microbes is an important mediator of the global carbon cycle and the marine carbon pool. Since the current reservoir of RDOC is compa- rable to the inventory of atmospheric $\mathrm{CO}_{2}$ (Hansell et al., 2009), trade off between the two carbon pools would influence climate change. Hence the relative rates of POC export, production of RDOC and respiration of POC and DOC regulate the timescale over which carbon is stored in the ocean's interior, and small changes to these rates would have a major, potentially detrimental, impact on atmospheric $\mathrm{CO}_{2}$.

While numerous experiments have assessed the sensitivity of POC export to changes in stratification, mixing and remineralization depth (Kriest et al., 2010; Romanou et al., 2014), little attention has been paid to the environmental factors and anthropogenic perturbations, such as ocean acidification (OA) and eutrophication, which might control the rates of RDOC production and transformation. Given the vast abundance and diversity of microbes (ranging from autoand heterotrophic prokaryotes through to photoauto-, mixoand phagoheterotrophic protists), the complexity of microbial ecosystems and the sensitivity of microbes to environmental change, small shifts in microbial metabolic efficiency potentially cause large changes to carbon sequestration (Mitra et al., 2014). Without fully understanding the microbial processes, we risk overlooking a crucial feedback of the overall system that is caused by a seemingly minor perturbation of an individual process.

The production and transformation of RDOC is intricately linked with the production and transformation of POC; thus it is timely to investigate these interactions. It is not known whether the cycling of POC and DOC would interact to enhance or decrease their individual effects, but it is possible that perturbations such as eutrophication or increasing temperature could cause a shift in the balance of carbon sequestration via dissolved versus particulate forms. In addition, their combined response to environmental conditions may be regulated differently under different conditions, for example, in coastal eutrophic waters compared to oceanic oligotrophic waters.

A multidisciplinary effort is required to address these challenges. To this end, the international IGBP/SCOR programme Integrated Marine Biogeochemistry and Ecosystem Research (IMBER), convened a workshop entitled "The impact of anthropogenic perturbations on open ocean carbon sequestration via the dissolved and particulate phases of the biological carbon pump", at the IMBIZO III conference in Goa, India, in January 2013. Microbial ecologists, marine biogeochemists, organic chemists, climatologists, fisheries scientists and economists presented recent research on the biological and microbial carbon pumps, discussed future natural and social science research needs to integrate POC and DOC research, and brainstormed to better understand the microbial carbon storage mechanisms of the ocean.

The objective of this paper is to identify the challenges of and devise strategies for the integration of observations and models of ocean POC and DOC cycling and sequestration, with reference to the chemical composition of marine DOC, the microbial processing of DOC, the environmental controls 
on the composition and processing of DOC, interactions between POC and DOC cycling, impacts of anthropogenic perturbations on the BP and MCP in different environments, and approaches for ecosystem sustainability and management.

\section{The nature and controls of DOC in the ocean}

Most of the DOC produced by photosynthesis is labile and can be remineralized or assimilated by microbes within minutes to a few days (Fuhrman, 1987). The remaining DOC can be gradually degraded and transformed by microbes and abiotic processes to a huge variety of new compounds with residence times from days to months, decades, hundreds and even thousands of years (Sherr, 1988; Marchant and Scott, 1993). The oceanic DOC pool has been classified into two major classes: labile DOC (LDOC) which does not accumulate in the ocean due to rapid microbial turnover and recalcitrant DOC (RDOC) which serves as a reservoir until its eventual mineralization or removal. In some studies, RDOC is subdivided into fractions defined by their lifetimes: semilabile $(\sim 1.5$ years $)$, semi-refractory $(\sim 20$ years $)$, refractory $(\sim 16000$ years $)$ and ultra-refractory $(\sim 40000$ years $)$ (Hansell et al., 2012). Obviously there are major gaps between the timescales describing the recalcitrance of RDOC, to say nothing of the difference in definitions between scientific disciplines. While geochemists can define RDOC according to the ${ }^{14} \mathrm{C}$ age on timescales of thousands of years and modelers use the turnover rates as the basis of their definition for the different types of RDOC, microbiologists may identify RDOC according to the absence of the genes that encode the enzymes required to metabolize the specific RDOC compound with no link to the timescale required. Such differences must be identified and addressed to ensure the interdisciplinary collaborations needed for a comprehensive understanding of the interactions between microbes and their geochemical environment and the consequences of microbial processing of carbon on outgassing of $\mathrm{CO}_{2}$ and carbon sequestration.

While age can be used to identify RDOC, not all old DOC is RDOC. For example, petroleum components can be very old but when exposed to microbial action they can be rapidly decomposed. In addition, different microbes have different decomposition capabilities under different environmental conditions. Thus, recalcitrance can vary between different species, different functional groups and different environments (Carlson et al., 2011; Jiao et al., 2011; Kujawinski, 2011). The classification of RDOC as microbial speciesspecific, functional group-specific or environmental contextspecific recalcitrant could diminish confusion between biological and geochemical descriptions. Therefore we propose the term RDOC context $\left(\right.$ RDOC $\left._{t}\right)$ (Fig. 1).

For a better understanding of the nature and behavior of RDOC, effort needs to be directed to isolation of different DOC molecules and subsequent chemical analyses of

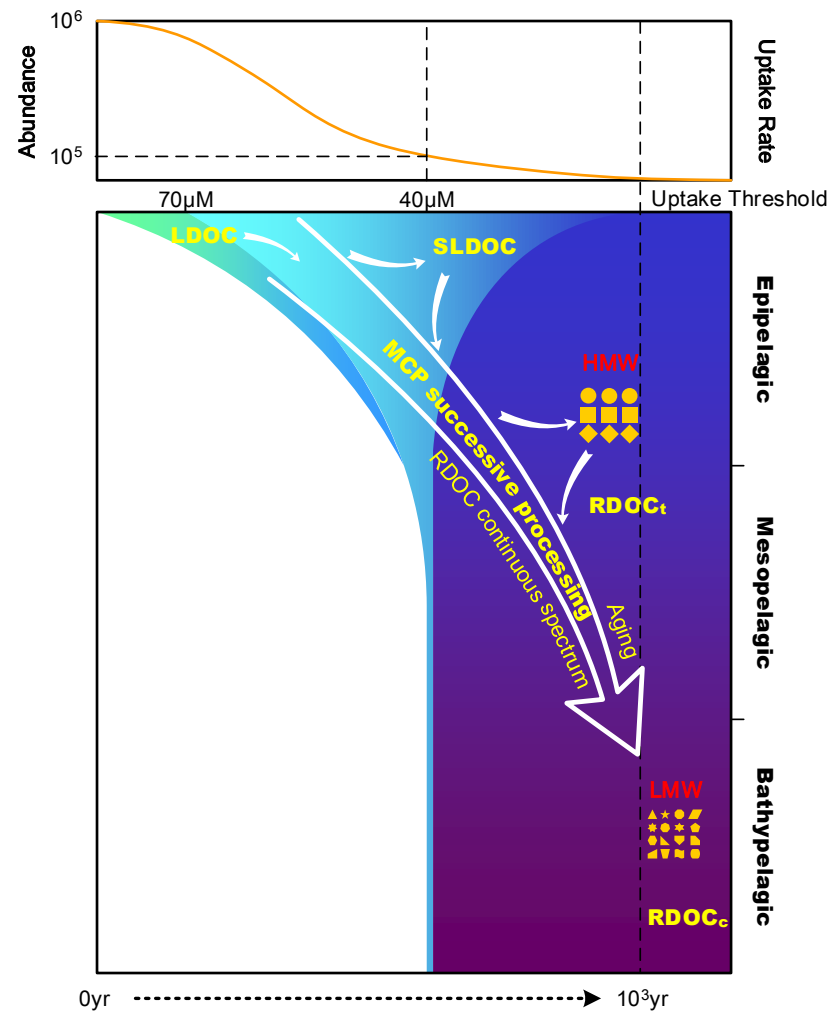

Figure 1. Linking RDOC at multiple dimensions: temporal (age) and spatial (depth) transformations of RDOC. Lower panel: successive microbial processing of organic carbon results in the generation of RDOC of different recalcitrance and different potential residence time; $\mathrm{MCP}$ - microbial carbon pump; $\mathrm{RDOC}_{\mathrm{t}}-\mathrm{RDOC}$ compounds that are resistant to microbial consumption in certain environments, but subject to further cleaving and decomposition when the situation changes; $\mathrm{RDOC}_{\mathrm{c}}$ - composed of diverse small molecules which are inaccessible to microbial uptake due to their low concentration. Upper panel: microbial response (in terms of abundance or uptake rate) to DOC availability as a reference to conceptualize the microbial uptake threshold for $\mathrm{RDOC}_{\mathrm{c}}$, microbial abundance corresponding to DOC concentrations of $40 \mu \mathrm{M}$ in the deep and $70 \mu \mathrm{M}$ in the surface oceans; LDOC - labile DOC, a fraction of DOC, which is immediately accessible to microbial utilization; SLDOC - semi-labile DOC, a fraction of DOC, which resides mainly in the upper layer but which becomes labile when transported to deep water.

the principal components of the DOC pool. One promising approach is ultrahigh-resolution mass spectrometry (Fourier transform ion cyclotron resonance mass spectrometry; FTICR-MS), which is based on the analysis of exact molecular masses from which the molecular elemental composition of marine DOM can be deduced (Koch et al., 2005; Hertkorn et al., 2006). To date several thousand molecular formulae have been identified and many of them may act as potential indicators for microbial sources and transformation processes (e.g., Kujawinski et al., 2004; Gonsior et al., 2009). Solid-phase extracted DOM is composed of highly oxygenated molecules (average oxygen to carbon ratio $\sim 0.45$ ), which implies that 
they should be utilizable by prokaryotes. This high oxygen content, which primarily exists in carboxylic functions, reflects a high degree of polarity and may therefore need a highly specific and energy-efficient uptake system by distinct microbes (Kattner et al., 2011). A low average proportion of hydrogen (average hydrogen to carbon ratio $\sim 1.25$ ) reflects a substantial proportion of stable aromatic backbones, structures known to be difficult for prokaryotes to degrade. Approximately one-third of the detectable formulae are present in all marine samples and most likely represent a common refractory background in DOM (Koch et al., 2005; Kattner et al., 2011). Within limits (on a molecular formula level), FT-ICR-MS allows us to distinguish between labile and refractory marine DOM generated within the MCP. D-Glucose incubations show that microbially derived marine DOM resembles labile material and that longer incubations are required to reach refractory element compositions (Koch et al., 2014). Recently, the chemical composition of DOM has been related to the degradation state and age of DOM (Flerus et al., 2012; Lechtenfeld et al., 2014). These studies reveal that the most persistent compounds encompass a very narrow range of average molecular elemental ratios $\mathrm{H} / \mathrm{C}$ and $\mathrm{O} / \mathrm{C}$ and show a continuum of residence times of refractory DOM in the ocean; the longest of which substantially exceeded the average age of marine DOC of $\sim 5000$ years (Bauer et al., 1992).

Besides describing the molecular composition of RDOC, understanding the microbial inaccessibility of RDOC is essential to determining why the ocean holds such a huge DOC pool in the presence of such an abundance of microbes. Appropriate (meta-) genomic and (meta-) transcriptomic methods are now available to examine the microbial genetic and enzymatic repertoire for cleaving and decomposing as well as taking up and transforming DOC compounds (Kujawinski, 2011). For example, the average genome of marine bacteria contains $3000-5000$ proteins, which according to comparative genomics analysis share similarities for primary metabolic pathways but differences for specific substrate assimilation.

Genes associated with cross-membrane transport, extracellular hydrolysis, motility and chemotaxis are critical for accessing the breadth of DOC molecules available for microbial assimilation. Roseobacter strains tend to assimilate carbohydrate-rich DOC while SAR11 bacteria prefer nitrogen-containing DOM because they have suites of highaffinity carbohydrate and amino acid $\mathrm{ABC}$ transporter systems, respectively (Jiao and Zheng, 2011). Bacteroides and Gammaproteobacteria are able to consume a diverse array of DOC because they have TonB-dependent transporter genes (Tang et al., 2012). Bacteroides can take up and assimilate $\mathrm{N}$-acetyl glucosamine while SAR11 cannot, due to a lack of $\mathrm{N}$-acetyl glucosamine transporter and its deacetylase. Genes associated with motility and chemotaxis vary from $\sim 0.5$ to $\sim 1.2 \%$ in the metagenomes of common marine environments. These genes provide a mechanism by which microor- ganisms can respond to microscale DOC gradients and access nutrient-enriched patches (Stocker, 2012).

High-molecular-weight (HMW) compounds must be cleaved into smaller chemical units by extracellular enzymes before microbial uptake (Arnosti, 2011). It is hard for cell wall materials such as peptidoglycan (accounting for $2 \%$ of the cell biomass) (Park and Uehara, 2008) to be decomposed completely when they are released as fragments into the environment during viral lysis or grazing processes. Usually heterotrophic prokaryotes need at least seven combined enzymatic transformations to cleave and decompose peptidoglycan for reutilization (Jiang et al., 2010). Even if peptidoglycan is cleaved, the fragments containing certain components such as $\mathrm{N}$-acetylglucosamine- $\mathrm{N}$-acetylmuramic acid and anhydro- $\mathrm{N}$-acetylmuramic acid can remain inaccessible to the uptake and assimilation systems of some microbes; however, many heterotrophic prokaryotes can take up and metabolize N-acetylglucosamine (Riemann and Azam, 2002). Although D-amino acids can be transformed into Lamino acids by racemases inside the cell (Jørgensen and Middelboe, 2006), the transformation can not be carried out extracellularly, and if no membrane transporter is available then this leads to the accumulation of D-amino acids in the water column as RDOC. Structural RDOC molecules, such as many D-amino acids (D-cysteine, D-tryptophan, Dtyrosine), are intrinsically very resistant to microbial utilization. Theoretically, an organic molecule/compound can be intrinsically recalcitrant to a specific microbial species or functional group if the microbes do not have the gene that encodes the corresponding enzyme to take up or decompose the molecule/compound. However, in the natural environment of diverse microbes and variable conditions, all RDOC molecules/compounds are in a transitional stage, subject to further cleaving or decomposition, and their recalcitrance is a continuum dependent upon microbial community structure and environmental conditions. Throughout the water column, microbial processing alters the nature of DOC through decomposition, assimilation and regeneration. Microbes can produce complex structures, such as biofilms, and low molecular weight (LMW) molecules such as antibiotics, toxins and virulence factors. In addition, in the surface water, photochemical reactions alter the composition of DOC, produce LMW organic compounds (Kieber et al., 1990) and influence the availability of DOC to microbes. The successive and repetitive processing of DOC compounds by the diverse prokaryote community could generate smaller and smaller fragments forming a LMW DOC pool. Although the total concentration of this LMW DOC pool is not low ( $\sim 40 \mu \mathrm{M}$, about half of the surface ocean DOC concentration), since it is composed of billions of different molecular species (Baldock et al., 2004; Koch et al., 2005), the concentration of most individual LMW DOC constituents would be extremely low. This, rather than their recalcitrance, could prevent energy-efficient microbial uptake (Kattner et al., 2011; Stocker, 2012). Although microbes are able to 
exploit substrates at very low concentrations, a low threshold exists (Jannasch, 1995) for energetically profitable substrate utilization (Barber, 1968; Kattner et al., 2011). These LMW DOC molecules would stay inaccessible to microbial uptake until they accumulate to a threshold level.

Based on the above considerations, RDOC can be classified into two categories, environmental context-dependent $\mathrm{RDOC}_{t}$ and concentration-constrained RDOC $\left(\mathrm{RDOC}_{\mathrm{c}}\right)$. $\mathrm{RDOC}_{\mathrm{t}}$ would be recalcitrant in a given biogeochemical context but could become accessible to microbial degradation in a different context, $\mathrm{RDOC}_{\mathrm{c}}$ would be composed of molecules at extremely low individual concentrations, which are below the corresponding microbial uptake thresholds. Organic carbon ages as it is transformed gradually and successively from labile to recalcitrant, from young HMW compounds in the upper ocean to old LMW compounds in the deep ocean, thus creating the continuum between microbial and geochemical processing of RDOC in the ocean (Fig. 1).

\section{RDOC processing in current and ancient oceans}

The activity of marine microorganisms leaves fingerprints in the geological records that are traceable using organic biomarkers and stable carbon isotopes. Thus integration of microbial identity and function with stable carbon isotopes on a geological timescale can improve our understanding of the mechanisms and processes of DOC production, accumulation and transformation in the modern ocean as well as their relationships with climate variability.

In addition to its present-day role, the MCP may have been crucial in the formation of a huge RDOC reservoir in the Precambrian Ocean. A MCP mediated by sulfate-reducing or iron-reducing microbes under hypoxic or anoxic conditions may have facilitated the accumulation of authigenic carbonate (i.e., derived from DOC) in sediments or bottom water, which may have played an important role in the global carbon budget through Earth's history (Canfield and Kump, 2013; Schrag et al., 2013).

Geochemical records indicate an intensive prokaryote driven MCP, and production of a large RDOC reservoir in ancient oceans. Logan et al. (1995) found that the $n$-alkyl lipids preserved in Proterozoic rocks are generally isotopically heavier than coexisting isoprenoidal lipids, while the opposite is observed for most modern and Phanerozoic sediments. This suggests that in the Proterozoic ocean, the $n$ alkyl lipids received stronger heterotrophic reworking than recalcitrant isoprenoidal lipids and that the MCP was therefore stronger in the Proterozoic oceans relative to that in modern and Phanerozoic oceans. A strong negative shift (down to $-15 \%$ ) in the $\mathrm{C}$-isotopic composition of sedimentary carbonates alongside a generally unchanged $\mathrm{C}$-isotopic composition of coexisting organic matter (Fike et al., 2006; Swanson-Hysell et al., 2010; Grotzinger et al., 2011) during the Neoproterozoic $(\sim 0.85$ to $0.54 \mathrm{Ga}$ ) has been proposed to indicate the presence of an unusually large RDOC reservoir at this time (Rothman et al., 2003).

The development of this large RDOC reservoir coincided with a series of extreme "snowball Earth" glaciations (Swanson-Hysell et al., 2010), culminating in the birth of the earliest animals on Earth (Fike et al., 2006; McFadden et al., 2008). It is likely that the great glaciations set up a lateral gradient of oxidants in the postglacial oceans (Li et al., 2010), which not only favored an intensive anaerobic MCP in shallow subsurface waters, but also created an extremely reduced deep ocean for storage of the resulting RDOC; these favorable geochemical conditions allowed the accumulation of the largest ocean RDOC reservoir known in the Earth's history (at least $10^{2}-10^{3}$ times larger than the modern RDOC reservoir in size and $10^{4}$ years longer in turnover time, Rothman et al., 2003). Further work is required on the biogeochemical mechanisms and effects of the unusual accumulation of RDOC in the Neoproterozoic deep ocean, as understanding the processes involved in the MCP in the deep past is important to improve our predictive capability for a future ocean, where anoxia is likely to increase (and thus potentially increase the ocean carbon storage capacity via the RDOC reservoir).

\section{Interactions between POC and DOC sequestration}

Differentiation of carbon sequestration to either the particulate or dissolved phase depends on the size threshold used to divide POC from DOC, and the lifetime of the various size fractions. Organic matter produced by the marine food web covers a size range of almost 10 orders of magnitude, from the smallest organic molecules (e.g., glucose, $0.7 \mathrm{~nm}$ ) to baleen whales (up to $30 \mathrm{~m}$ ). For convenience, researchers divide this size range into DOC and POC (the threshold depending on the filter used to retain particles), but actually the size distribution is almost continuous. The lifetime of any substance is defined, assuming exponential decay, as the time over which its concentration decreases to $1 / e$ of its initial value, where $e$ is the Napierian constant 2.71828; this corresponds to the " $e$-folding lifetime", which is different from the related concept of "half-life" where $1 / 2$ is used instead of $1 / \mathrm{e}$ (Hansell, 2013). Organic matter has lifetimes that range from less than a day to tens of thousands of years. The rates of production of the DOC fractions defined by Hansell (2013) are inversely related to their average lifetimes, i.e., organic compounds with a long lifetime are produced at small rates according to the following equation (based on values given in Table 1 of Hansell, 2013):

$\log _{10}$ (production within a DOC fraction)

$=0.29-0.40 \log _{10}$ (average lifetime of the fraction),

with $r^{2}=0.96$. In addition, the intrinsic lifetimes of organic compounds may be significantly lengthened by their storage in geochemical reservoirs. For example, organic matter that 
sinks into deep water may be either remineralized (respired) to $\mathrm{CO}_{2}$ or buried in sediments. In the first case, the $\mathrm{CO}_{2}$ that is dissolved in deep waters will return to the atmosphere on average about 1000 years later. In the latter case, the organic carbon may be incorporated in sediments, carried by the ocean floor until it is subducted in trenches (the age of the ocean floor is generally $<125$ million years), and released to the atmosphere by volcanoes, or incorporated into continental rocks until ultimately released to the atmosphere by weathering.

The Intergovernmental Panel on Climate Change (IPCC, 2013) defines carbon sequestration as the addition of carbon containing substances to a reservoir, e.g., the ocean, which has the capacity to store, accumulate or release carbon. Economists are interested in the timescale of carbon sequestration because companies or countries can earn carbon credits by artificially capturing and securing the storage of carbon that would otherwise be emitted to or remain in the atmosphere. Within the context of ocean fertilization, Lampitt et al. (2008) proposed that sequestration requires carbon which persists at least 100 years. According to this 100-year timescale (e.g., Legendre and Le Fèvre, 1991, 1995; Legendre and Rassoulzadegan, 1996; Passow and Carlson, 2012), POC that reaches deep-ocean waters is sequestered, as are the most refractory fractions of RDOC. Carbon sequestration is also achieved by the solubility and the carbonate pumps (Volk and Hoffert, 1985).

The rate of POC sequestration can be estimated from the POC sinking flux measured in sediment traps at $2000 \mathrm{~m}$. Estimates of this flux range from $0.43 \mathrm{Pg} \mathrm{C}_{\text {year }}{ }^{-1}$ (Honjo et al., 2008) to $0.66 \mathrm{Pg} \mathrm{C}_{\text {year }}{ }^{-1}$ (Henson et al., 2012). The POC flux to the sediment is estimated to be $0.1-0.16 \mathrm{Pg} \mathrm{C}_{\text {year }}{ }^{-1}$ (Hedges and Keil, 1995; Prentice et al., 2001). In contrast, there are few estimates of the rate of DOC sequestration. Using the 100-year sequestration criterion, a minimum estimate would be the combined production rates of refractory and ultra-refractory DOC (average lifetimes of 16000 and 40000 years and production of 0.043 and $0.000012 \mathrm{PgC}_{\text {year }}{ }^{-1}$, respectively) (Hansell, 2013). In addition, at least part of the production of semi-refractory DOC should be included, since its average lifetime is 20 years (production of $0.34 \mathrm{Pg} \mathrm{C}_{\text {year }}{ }^{-1}$ ) (Hansell, 2013) and that of the next fraction, refractory DOC, is 16000 years. Hence the combined production rates of these three fractions of RDOC would be $0.38 \mathrm{PgC}_{\text {year }}{ }^{-1}$, roughly consistent to earlier estimates of 0.5-0.6 $\mathrm{Pg} \mathrm{C}_{\text {year }}{ }^{-1}$ (Brophy and Carlson, 1989). It seems that sequestration from the RDOC-based MCP and the POC-based BP are of the same order of magnitude.

Sequestration would be high when there is rapid downward transport of POC or substantial transformation of organic matter to RDOC. The interactions between POC flux and RDOC production are numerous. For example, the attenuation of POC flux is accompanied by DOC generation throughout the water column, while the microbial transformation of DOC can also be accompanied by the formation of

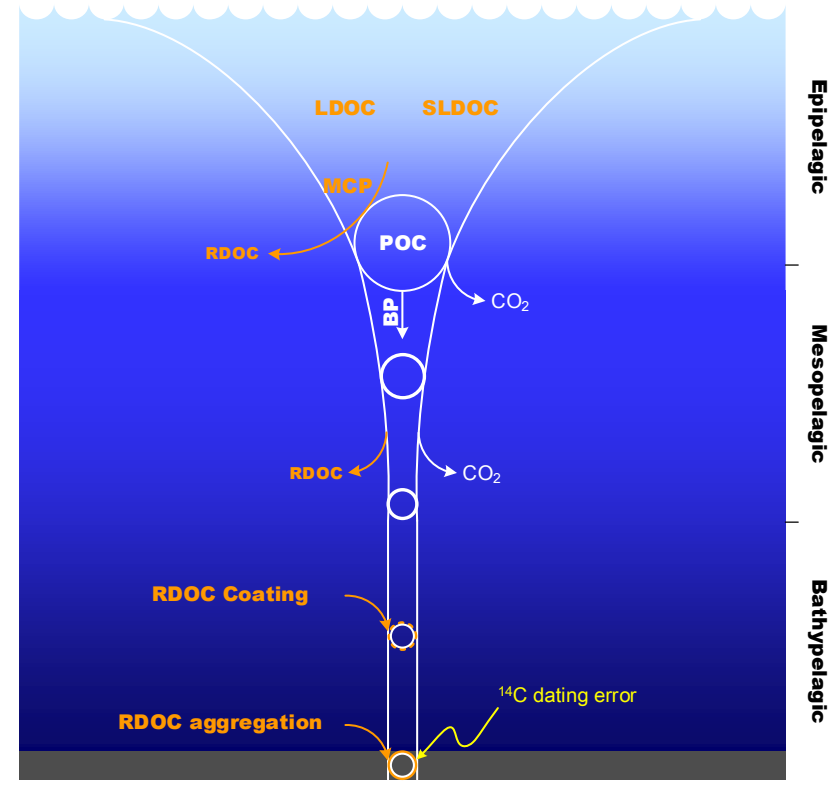

Figure 2. Transformation of DOC and POC through decomposition and scavenging processes that could influence carbon sequestration and ${ }^{14} \mathrm{C}$ dating (see text for details). $\mathrm{MCP}$ - microbial carbon pump, BP - biological pump, POC - particulate organic carbon, DOC dissolved organic carbon, LDOC - labile DOC, SLDOC - semilabile DOC, RDOC - refractory DOC, RDOC coating - the process of RDOC attaching to the exterior of or being incorporated into a particle, RDOC aggregation - the process of RDOC molecules accumulating and combining.

particles large enough to sink (Fig. 2). About $10 \%$ of marine DOC exists in the form of gels which harbor heterotrophic prokaryotes (Azam and Malfatti, 2007) and can accelerate carbon transformation (Ziervogel et al., 2011), while POC or aggregates attract copiotrophs such as Bacteroides (Arnosti et al., 2012) that have motility and chemotaxis genes and can potentially follow DOC gradients (Stocker, 2012). Many marine heterotrophic prokaryotes produce polysaccharides, which help them attach to biotic and abiotic surfaces to form aggregates. The matrix of the aggregate, known as extracellular polymeric substances (EPS) or transparent exopolymer particles (TEP), is composed of polysaccharides, proteins, nucleic acids and lipids. These cohesive, three-dimensional polymers interconnect cells, forming aggregates which then contribute to POC flux. Microbes colonize sinking aggregates, and can grow by means of exoenzymatic decomposition of the aggregated organic particles, which in turn could lead to a DOC plume following the sinking aggregate. In fact, this plume may account for a significant fraction of the microbial production and remineralization (Kiorboe and Jackson, 2001). Thus the balance between the rate at which aggregates form and sink on the one hand and the rate at which they are remineralized and secrete DOC on the other hand has a major impact on ocean carbon flux. It has been 
hypothesized that the strategy of heterotrophic prokaryotes in oligotrophic environments is to grow in biofilms on surfaces where nutrients are locally available, and to persist in nutrient-deprived zones such as floating biofilms with the capacity to return to optimum growth when nutrients again become available (Costerton et al., 1995). This is supported by evidence suggesting that carbon-limited deep-ocean prokaryotes show a preferential particle-related life strategy (DeLong et al., 2006; Arístegui et al., 2009; Baltar et al., 2009, 2010b).

Aggregating and scavenging processes are common in the water column. Sinking POC particles could be nuclei for RDOC molecules to attach to or aggregate with (Druffel and Williams, 1990; Hwang and Druffel, 2003; Roland et al., 2008). If the POC particles scavenge enough RDOC molecules, they could become coated with RDOC (Fig. 2). As POC is relatively labile, it is considered to be an important food source for deep ocean microbes. In the case of "RDOC-coated POC", since RDOC is resistant to microbial utilization, if the POC particle is coated with enough RDOC, molecules, it is theoretically no longer subject to microbial attack and can safely reach the seabed where it can be buried for millions of years. In a simplified scenario that a spherical particle with diameter of $d$ is sinking directly from the bottom of the euphotic zone to the sea floor, the carbon content of this particle is

$\mathrm{POC}=\frac{4}{3} \pi \cdot\left(\frac{d}{2}\right)^{3} \cdot \rho$,

where $\rho$ is the particle's carbon density. Assuming a weight density of the particle of $3 \mathrm{mg} \mathrm{mm}^{-3}$ (Carder et al., 1982) and the molar ratio of $106: 16: 1: 106$ for $\mathrm{C}: \mathrm{N}: \mathrm{P}: \mathrm{O}$ of the particle, we can estimate $\rho=0.1 \mathrm{mmol} \mathrm{C} \mathrm{mm}^{-3}$. If the depth from the bottom of the euphotic zone to the seabed is $z$, the path of the sinking particle forms a water column with diameter $d$ and length $z$, in which all the RDOC molecules $\left(\mathrm{RDOC}_{\mathrm{ect}}\right)$ are encountered by the particle:

$\mathrm{RDOC}_{\mathrm{ect}}=\pi \cdot\left(\frac{d}{2}\right)^{2} \cdot z \cdot[\mathrm{RDOC}]$.

We can estimate [RDOC] to be $40 \mu \mathrm{M}$ and $z$ to be $4000 \mathrm{~m}$ for the typical open ocean. If the probability that a RDOC molecule is scavenged by the particle is $p$, the carbon ratio of the RDOC and the original POC in this particle after reaching the sea floor is

$r=\frac{\mathrm{POC}}{\mathrm{RDOC}_{\mathrm{ect}} \cdot p}=\frac{2}{3} \cdot \frac{\rho}{z \cdot[\mathrm{RDOC}]} \cdot \frac{d}{p}$.

By using the parameter values we estimated above, Eq. (4) simplifies to

$r=2400 \cdot \frac{p}{d} \mathrm{~mm}^{-1}$.

This equation indicates that the ratio $r$ depends on the particle size and the scavenge probability. For a small particle with diameter of order $0.01 \mathrm{~mm}$, a very low scavenge probability $p=4 \times 10^{-6}$ will roughly give $r \approx 1$, i.e., about half of the carbon in the particle reaching the seabed is from RDOC. For a larger particle with diameter of $\sim 1 \mathrm{~mm}$, the same scavenge probability would predict that $\sim 1 \%$ of the carbon of the particle reaching the seabed is from RDOC.

This calculation is a simplification as it does not limit the maximum number of RDOC molecules that can be scavenged by a particle and does not consider eddies and currents generated by the sinking particles. In addition, if a particle does not sink directly to the sea floor but also moves horizontally or even upwards, its path can be even longer and so it would encounter more RDOC molecules.

Another effect of the "RDOC coating process" is bias in ${ }^{14} \mathrm{C}$ dating (Fig. 2). As indicated in the above calculation, assuming the average age of RDOC is 5000 year, a 1 year old POC particle landing at the seabed could be falsely dated as 50-2500 year old depending on its size $(0.01-1 \mathrm{~mm}) \mathrm{using}$ our assumed scavenge probability. In fact, one of the loss processes of RDOC in the water column is aggregation that ultimately leads to transfer of aged organic carbon as POC to the sediment (Engel et al., 2004b; Jiao et al., 2010a).

Physical processes such as stratification, mixing and ocean currents influence carbon sequestration in the ocean. Increasing stratification restricts nutrient supply from deep water to the euphotic zone, and therefore primary production which will in turn impact the export of POC (Doney, 2006; Capotondi et al., 2012; Passow and Carlson, 2012). Episodic vertical water movement such as solitary waves could enhance POC flux and these are thought to be responsible for the unexpected presence of Prochlorococcus in aphotic waters (300-1000 m) in the western Pacific marginal seas (Jiao et al., 2014). Mesoscale eddies are ubiquitous features in the ocean (Cheney and Richardson, 1976; Arístegui et al., 1997; van Haren et al., 2006), and could play a major role in the generation, accumulation and downward transport of biogenic production in the ocean. Cyclonic eddies enhance nutrient inputs to the surface ocean increasing new production (Falkowski et al., 1991; Harris et al., 1997; Moran et al., 2001) and chlorophyll concentrations (Arístegui et al., 1997; McGillicuddy Jr. et al., 1998; Tarran et al., 2001). The presence of eddies has also been related to increased bacterial abundance (Arístegui and Montero, 2005) and production (Bode et al., 2001; Baltar et al., 2007), even in the mesopelagic zone (Baltar et al., 2010a). However, the contribution of eddies to particle flux is still poorly constrained. Mesoscale eddies were shown to enhance POC export by a factor of 2-4 (Alonso-González et al., 2010) in the Canary Island region, whereas eddies in Hawaii did not increase the efficiency of POC export to mesopelagic waters as most of the particle production was rapidly remineralized in the upper $150 \mathrm{~m}$ (Maiti et al., 2008).

A recent study of cyclonic eddies in the western South China Sea (Jiao et al., 2014) suggested that the intensity, timing and duration of nutrient input influenced the 
plankton community structure which affected whether eddy induced upwelling was associated with an increase (diatom dominated) or decrease (dominance of cyanobacteria) in POC flux. Legendre and Le Fèvre (1995) previously stressed the significant role of the microbial food web in carbon export. Along a nutrient gradient from eutrophy to oligotrophy, POC export decreases as there is a transition in the structure of the microbial food web from phytoplankton prey-microzooplankton predators to picoplanktonic cyanobacteria, heterotrophic bacteria, and Archaea prey and mixotrophic protist predators (Zubkov and Tarran, 2008; Hartmann et al., 2012). The ratio of DOC production to total primary production increases with increasing oligotrophy (Teira et al., 2001), with some of this DOC likely converted to RDOC. Thus, the contribution of the MCP to carbon storage could be expected to be relatively high in the oligotrophic ocean. A similar transition from dominance of the BP to dominance of the MCP might be expected along a latitudinal gradient from polar regions to the tropics and from surface waters to the mesopelagic (Fig. 3).

\section{Impact of anthropogenic perturbations on carbon sequestration}

\subsection{Relevance to society}

The BP and MCP operate in concert to keep a large reservoir of carbon out of the atmosphere by storing POC, DOC and dissolved inorganic carbon (DIC) in the ocean. Without marine biological carbon sequestration, it has been estimated that the atmospheric $\mathrm{CO}_{2}$ concentration would be $50 \%(200 \mathrm{ppmv})$ higher than the current value (Parekh et al., 2006). This storage of carbon thus has intrinsic value as an "ecosystem service" (e.g., Luisetti et al., 2011). The term "blue carbon" has previously been applied to coastal ecosystems which have the capacity to store carbon year-on-year, with the intention of valuation and possible subsequent carbon trading (Ullman et al., 2013) but that definition has not previously been extended to continental shelf sediments or the open ocean (Grimsditch et al., 2013).

The deep-ocean natural carbon store is relatively secure on short (decadal to centennial) timescales due to the long residence times of DIC $\left(10^{3}\right.$ years $)$ and DOC $\left(10^{4}\right.$ years $)$ in the deep ocean. More relevant to society and how our activities may impact this system is the balance between input and output terms of the ocean carbon inventory. Any action we can take to increase the efficiency of the BP and MCP, or reduce the rate of the return pathway(s), will lead to net accumulation of carbon in the deep ocean. Assuming the net biological pump (BP+MCP) is $\sim 1-10 \mathrm{Pg} \mathrm{C}_{\text {year }}{ }^{-1}$ (IPCC, 2013), this represents roughly $1-10 \%$ of net global primary production and between 10 and $100 \%$ of global anthropogenic $\mathrm{CO}_{2}$ emissions. Thus, for example, a $10 \%$ increase in the annual input term to the ocean carbon store could lead to sig-

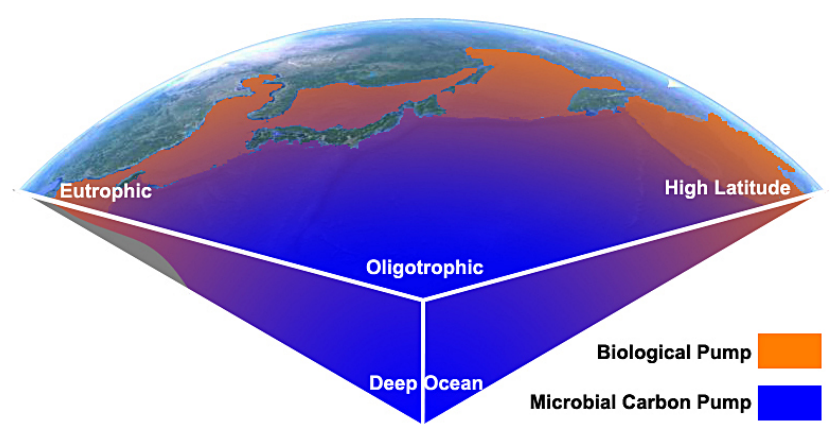

Figure 3. A demonstration of trends in the relative dominance of the $\mathrm{BP}$ and the MCP along environmental gradients.

nificant additional annual carbon sequestration. Conversely, a decrease of the input term or increase to the output could lead to significant additional emissions. Thus understanding the interactions between our actions (and their subsequent effects) and the efficiency of the BP and MCP are of particular importance, both for understanding the likely response to future global change and in informing whether or how marine management options might be employed to enhance (or reduce degradation of) pump efficiency.

Many of the interactions over which we may be able to exercise management options take place in shelf seas, which are active areas for DOM cycling (Prowe et al., 2009; Johnson et al., 2013) and carbon export (Tsunogai and Noriki, 1991; Thomas et al., 2004). Although covering only $8 \%$ of the ocean's surface area, they account for $20 \%$ of the ocean's capacity to absorb $\mathrm{CO}_{2}$ (Thomas et al., 2004). Shelf seas are also the regions subject to strongest human pressures (Emeis et al., 2014), thus they represent a strong "pressure point" for controlling BP and MCP efficacy. These human pressures include nutrient input, hypoxia and trawling amongst others, and we do not yet know how these pressures or combinations of pressures will affect carbon storage. In the following section, we consider the potential effects of two important anthropogenic forcings: (i) nutrient input to the oceans (a largely shelf sea pressure) and (ii) ocean acidification (a global pressure).

\subsection{Nutrient supply}

Generally, an increase in nutrient supply to coastal waters is expected to lead to an increase in primary production, POC, and consequently an increase of the BP. However, high nutrient concentrations could have a negative impact on the MCP (Jiao et al., 2010b). Primary production, bacterial respiration and bacterial growth efficiency would respond differently to increasing nutrients (Fig. 4). As phytoplankton populations increase with increasing nutrients, a maximum will be reached when light shading becomes important and primary production starts to decrease. In contrast, providing DOC was in adequate supply, heterotrophic bacterial growth 


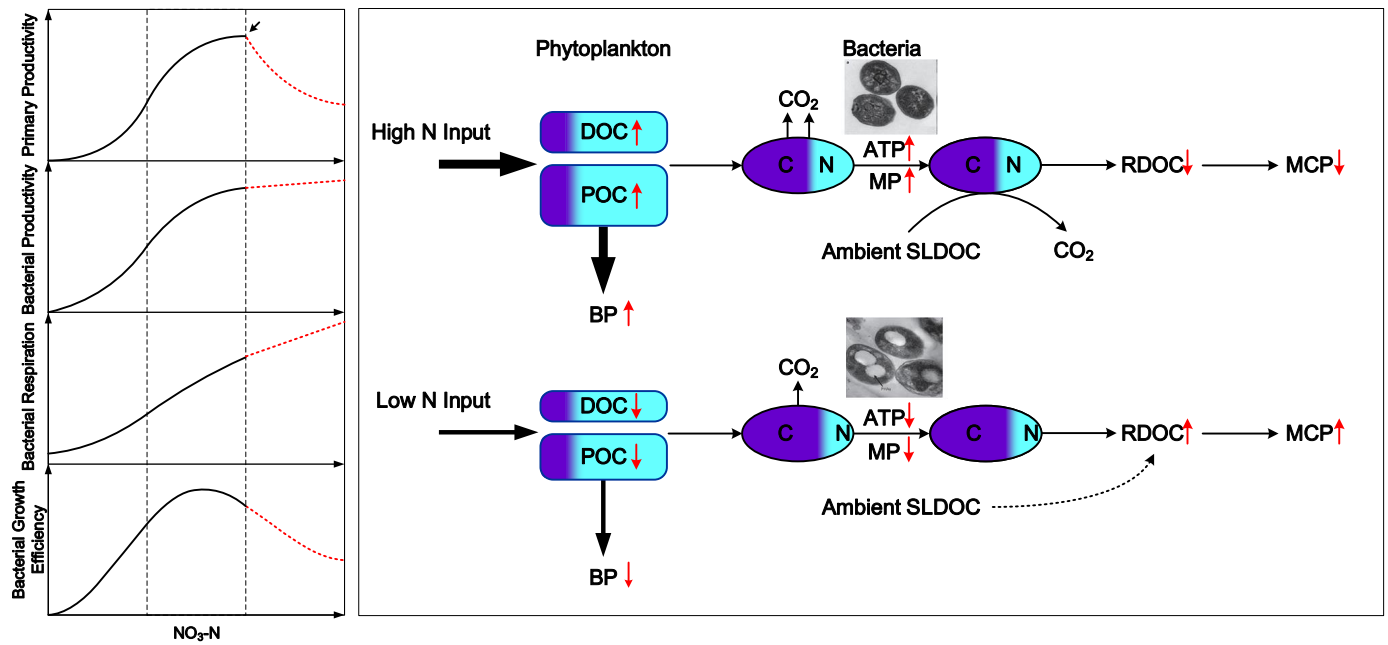

Figure 4. The impact of nutrient supply on the sequestration of carbon via the BP and the MCP. Left panel: primary production, bacterial respiration and bacterial growth efficiency as functions of nutrients. The arrow in the top graph shows a tipping point of nutrient concentration beyond which primary production could drop down due to the constrains of limiting factors other than nutrients, such as light availability and environmental carrying capacity. The red lines after the tipping point emphasize the differences between phytoplankton and bacteria in their response to high nutrients. The appropriate nutrient concentrations for a healthy ecosystem would range between the vertical dashed lines where the ecosystem could remain sustainable while running at a high level of biological efficiency. Right panel: responses of the BP and the MCP to nutrient inputs. (MP - membrane potential; ATP-adenosine triphosphate). With high nutrient input, although the BP could be enhanced, the MCP could be reduced, because microbial respiration can also be stimulated by nutrients. Meanwhile ambient semi-labile DOC could be remobilized for microbial utilization, especially with the priming effects of the labile DOC generated by enhanced primary production. In contrast, if nutrient input is appropriate, the BP could remain moderate, semi-labile DOC could remain persistent, the MCP could be enhanced, and the storage capacity of the combined BP and MCP could be maximized.

would be less influenced by the light field. The phytoplankton bloom would provide a steady supply of labile DOC for bacterial growth, together with riverine-derived semi-labile DOC (SL-DOC) (Fig. 4). Oxygen consumption due to this bacterial respiration can eventually lead to hypoxia. Under hypoxic and anoxic conditions, anaerobic bacteria would degrade the remaining organic matter, generating gases such as methane and $\mathrm{H}_{2} \mathrm{~S}$. The former is a potent greenhouse gas and the latter is a potential source of acidic rain (Fig. 5). Such scenarios could have occurred during geological events in the history of the Earth. In terms of carbon preservation, even if more carbon is fixed, it does not necessarily lead to increased carbon storage. This is verified by a systematic field survey which indicated an inverse correlation between nitrate and organic carbon in all terrestrial and marine environments (Taylor and Townsend, 2010). Thus excess nutrients can lead to lower organic carbon storage.

On the other hand, if nutrient input were reduced, although the $\mathrm{BP}$ is apparently decreased, the organic matter that is produced would have relatively high $\mathrm{C} / \mathrm{N}$ or $\mathrm{C} / \mathrm{P}$ ratios, and thus be of poor food quality for zooplankton resulting in high ingestion and gut transit rates and low digestion. Such organic matter would also be relatively resistant to microbial utilization, enhancing the MCP. Microbial carbon accumulation is known to occur where/when nutrients are limiting (Carlson et al., 2002; Gasol et al., 2009; Lauro et al., 2009;

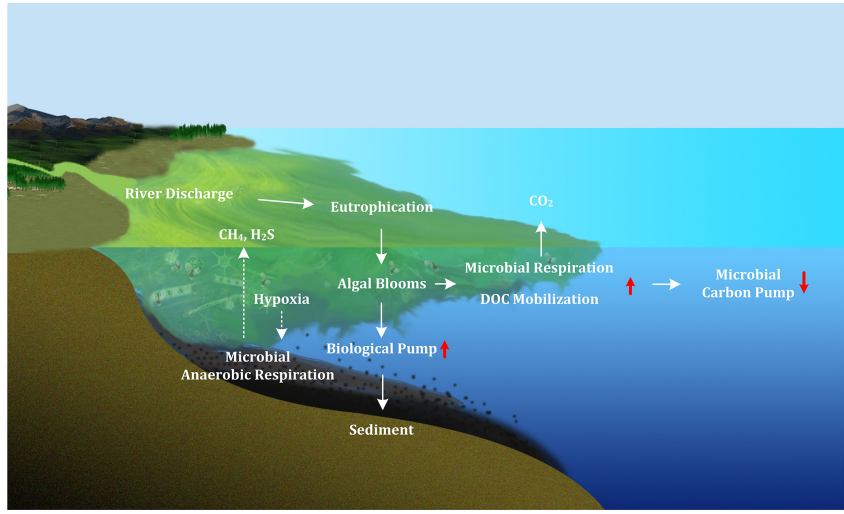

Figure 5. Hypothesized consequences of excess nutrients in coastal waters. Excess nutrients from river discharge cause eutrophication, harmful algal blooms and hypoxia, which in turn influence overall carbon sequestration efficiency.

Thomas et al., 1999; Jiao et al., 2010b). For example, in postbloom, nutrient depleted conditions in temperate systems, net $\mathrm{CO}_{2}$ fixation continues with the carbon likely being stored in high $\mathrm{C} / \mathrm{N}$ or high $\mathrm{C} / \mathrm{P}$ DOM, while the POC/PON still approximates Redfield values (Craig et al., 2013). In support of this, oceanic DOC concentrations tend to be highest in the low nutrient oligotrophic gyres (Hansell et al., 2009). Even in 
eutrophic waters, as long as the $\mathrm{C} / \mathrm{N}$ ratio reaches a threshold value, microbial cells will start to store carbon and produce more recalcitrant compounds or polymers (Bhaskar and Bhosle, 2005; Kadouri et al., 2005; Jiao et al, 2010b). In a 14-day in situ nutrient enrichment experiment undertaken in the western Pacific oligotrophic gyre, more than $30 \%$ of the ambient organic carbon was respired in the incubation with addition of inorganic nutrients compared to the control (Liu et al., 2014).

\subsection{Ocean acidification}

The absorption of $\mathrm{CO}_{2}$ by the ocean results in an increase in the partial pressure of $\mathrm{CO}_{2}\left(p \mathrm{CO}_{2}\right)$, bicarbonate ion $\left[\mathrm{HCO}_{3}^{-}\right]$ and hydrogen ion $\left[\mathrm{H}^{+}\right]$concentration, and a decrease in carbonate ion concentration $\left[\mathrm{CO}_{3}^{2-}\right]$ - so-called ocean acidification (OA) (Doney et al., 2009). Enhanced photosynthesis and nitrogen fixation have been shown to occur under higher $p \mathrm{CO}_{2}$ conditions in laboratory and field experiments (Fu et al., 2007; Riebesell and Tortell, 2011). Phytoplankton production of TEP is stimulated by higher $p \mathrm{CO}_{2}$ treatments at both species and community levels (Engel, 2002; Engel et al., 2004a; Mari, 2008; Pedrotti et al., 2012), which contributes to the formation of aggregates and so the vertical flux of POC and DOC. OA inhibits phytoplankton calcification which will decrease the ballast effect of calcium carbonate, so decreasing the vertical transport of POC (Barker et al., 2003). In addition, the efficient degradation of TEP by marine microbes (Koch et al., 2014) may be enhanced at lower pH (Piontek et al., 2010). Shifts in phytoplankton community structure have occurred in high $\mathrm{CO}_{2}$ treatments that could impact the composition and bioavailability of the DOC produced (Tortell et al., 2002; Paulino et al., 2008; Brussaard et al., 2013). Although there is no clear impact of OA on bacterial abundance (Rochelle-Newall et al., 2004; Grossart et al., 2006; Allgaier et al., 2008; Paulino et al., 2008; Newbold et al., 2012; Brussaard et al., 2013), gross- and cellspecific bacterial production are usually stimulated by high p $\mathrm{CO}_{2}$ treatments (Grossart et al., 2006; Allgaier et al., 2008; Motegi et al., 2013; Piontek et al., 2013). The activity of bacterial protease, glucosidase and leucine-aminopeptidase is also stimulated by higher $p \mathrm{CO}_{2}$ (Grossart et al., 2006; Piontek et al., 2010, 2013). Changes in the community structure of bacterioplankton were observed when $p \mathrm{CO}_{2}$ was artificially adjusted (Allgaier et al., 2008; Newbold et al., 2012; Zhang et al., 2013). However, it is possible that the observed responses of bacterioplankton to OA are due to tight coupling of phytoplankton and heterotrophs in experiments with whole water samples. Nevertheless, higher bacterial activities in high $p \mathrm{CO}_{2}$ conditions may reduce carbon sequestration by POC flux but enhance the efficiency of the MCP by producing more RDOC (Piontek et al., 2010, 2013). Indeed, Kim et al. (2011) found an enhanced DOC: POC production ratio in higher $p \mathrm{CO}_{2}$ treatments in a mesocosm study. Still, we have a very limited understanding of ecological processes (such as viral lysis and grazing) involved in both POC and DOC cycling under high $\mathrm{CO}_{2}$ conditions.

\section{Strategies for future research to maximize carbon storage in the ocean}

\subsection{Monitoring}

Satellite remote sensing of the surface ocean's optical properties (ocean color) has been fundamental in developing the prevailing view of global ocean phytoplankton production and the BP. However, standard band-ratio chlorophyll products, designed for "Class I" open ocean waters, have limitations when dealing with other optically active constituents related to DOC transformation. The premise underpinning the "Class I" water classification is that all optical properties co-vary with phytoplankton. However, increasing evidence that aged DOC occurs at significant concentrations in the open ocean (Hansell et al., 2009), independent of phytoplankton dynamics, may require this assumption to be reevaluated. A range of products have been developed that give an indication of the surface distributions of pools of organic carbon constituents in the ocean, including colored (or chromophoric) dissolved organic material (CDOM; Siegel et al., 2002, 2005; Maritorena and Siegel, 2005; Morel and Gentili, 2009), DOC (Mannino et al., 2008), POC (Stramski et al., 1999; Loisel et al., 2002; Gardner et al., 2006; Sathyendranath et al., 2009; Stramska, 2009), phytoplankton size classes (PSC; Ciotti and Bricaud, 2006; Hirata et al., 2008a, 2011; Brewin et al., 2010a, b; Uitz et al., 2010; Devred et al., 2011) and particle size distribution (PSD; Hirata et al., 2008b; Kostadinov et al., 2009, 2010). Key uncertainties relate to the relationship between the absorption of light by CDOM and concentrations of DOC and to the contribution of very small particles (e.g., viruses) to particle backscattering signals used in the derivation of POC and PSD products (Stramski et al., 2008; Dall'Olmo et al., 2009).

The major limitation of using satellite observations for investigation of the MCP is that they are restricted to surface layers of the ocean. Nonetheless, there may be some regions and seasons where this limitation can be partially overcome, for example, in upwelling regions or regions of deep seasonal overturning, where deeper DOC-rich waters are mixed to the surface. Recent advances in sub-surface remote sensing, by the addition of biogeochemical and optical sensors to profiling floats (such as those deployed in the Argo array), provide a new opportunity to investigate distributions of CDOM and POC throughout the water column, extending our knowledge of surface bio-optical distributions into the interior ocean and connecting them with environmental gradients in nutrients, oxygen and $\mathrm{pH}$ (Johnson et al., 2009). Future incorporation on the floats of novel sensors for rapid characterization of genetic material in situ would significantly advance our ability 

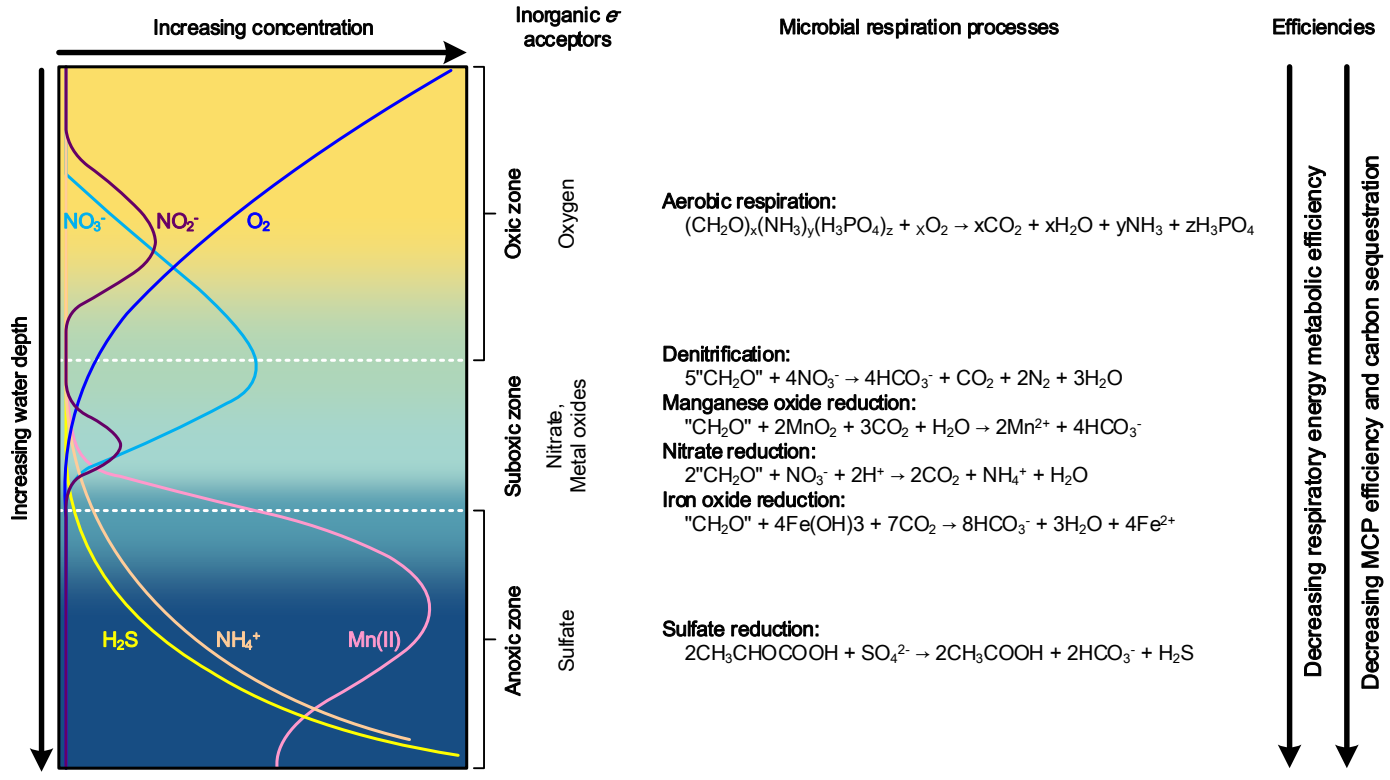

Figure 6. The influence of microbial respiration processes on the efficiency of the MCP. Left panel after Moore et al. (2009).

to describe prokaryote diversity throughout the water column alongside a better characterization of DOM.

Marine biogeochemical time series data sets, such as the Hawaii Ocean Time-Series (HOT), the Bermuda Atlantic Time-Series Study (BATS) and the Porcupine Abyssal Plain (PAP) Observatory are vital to the study of inter-annual variability in the linkage between phyto- and bacterioplankton community structure and the BP and MCP (Carlson et al., 2004; Bidigare et al., 2009). These single point data sets are complemented with transect time series data sets such as the Atlantic Meridional Transect (Robinson et al., 2006) and multi-decadal biological data sets such as those collected with the Continuous Plankton Recorder (CPR; Hinder et al., 2012). Data from the CPR survey show the link between climate variability and the dominant phytoplankton functional group (PFG) (Hays et al., 2005), and a global collation of sediment trap data demonstrate the relationship between dominant PFG and POC export efficiency and transfer efficiency (Henson et al., 2012). Inclusion of measurements of DOC quantity, quality and reactivity alongside microbial community structure in these monitoring programmes would improve our understanding of linkages between climate-derived changes in plankton community structure and oceanic storage of organic carbon.

\subsection{Environmental context}

The sequestration of carbon in the ocean is indispensably linked to the cycling of nitrogen, phosphorus, sulfur and iron. Bacterial and Archaeal activities contribute to the regeneration of $\mathrm{N}$ and $\mathrm{P}$ by consuming DOC (White et al., 2012). Complex interactions between prokaryotes and eu- karyotic microbes, such as cooperation or competition for nutrients, exist in the marine environment. For example, Mitra et al. (2014) have proposed a new paradigm where, in oligotrophic waters, the mixotrophic protists through production of DOM effectively engage in "bacterial farming" to ensure ample provision of food. Thus, in different biogeochemical environments, the MCP could be expected to operate with different efficiencies for carbon storage.

An example of the changing efficiency of DOC-derived carbon sequestration is that which occurs along an estuarine gradient. Due to high terrigenous input of nutrients and organic matter, estuarine ecosystems usually experience intense heterotrophic respiration processes that rapidly consume dissolved oxygen, potentially producing extensive hypoxic and anoxic zones in the water column. The lowered availability of dissolved oxygen and the increased load of nutrients such as nitrate from river input prompt enhanced anaerobic respiration processes. Thus, most of the nutrients may be consumed by anaerobically respiring heterotrophic microorganisms instead of being utilized by phytoplankton for POC and DOC production (Fig. 6). Anthropogenic eutrophication in estuarine and coastal areas may thus reduce the efficiency of the MCP (Dang and Jiao, 2014). This reduced efficiency may be exacerbated by the potential "priming" effect of labile organic matter addition stimulating the respiration of RDOC, as recently seen in soil environments (Wieder et al., 2013).

\subsection{Bioassay and perturbation experiments}

In order to investigate mechanistic relationships between changing environmental parameters such as temperature, $\mathrm{OA}$ 
and nutrients, and microbial organic carbon cycling, bioassay or manipulation experiments are required. Mesocosm experiments have become the preferred approach for these manipulations due to their ability to (a) study community dynamics of three or more trophic levels for a prolonged period of time, (b) measure the pools and fluxes of bio-active compounds and to perform mass balance estimates, and (c) study the interactions of ecosystem dynamics and biogeochemical processes under defined experimental conditions (Riebesell et al., 2013).

Mesocosm experiments have been instrumental in observing the influence of OA on DOC concentration (Schulz et al., 2008), TEP production (Engel et al., 2004a) and community respiration (Egge et al., 2009), the impact of nutrient supply on production, partitioning and the elemental composition of dissolved and particulate material (DOM, POM), and the impact of increasing temperatures on the accumulation and stoichiometry of DOM and POM (Wohlers-Zöllner et al., 2012), the coupling of phytoplankton and bacterial processes (Hoppe et al., 2008) and the balance between autotrophic and heterotrophic metabolism (Müren et al., 2005).

Most data on the effect of climate change on organic matter dynamics were obtained in perturbation experiments studying the response to a single factor. Recent data highlight the need to study the interactions between multiple drivers (e.g., temperature, nutrients, light and OA). For example, the contradictory responses of phytoplankton TEP production to OA (Engel et al., 2004a; Schulz et al., 2008; Egge et al., 2009) indicates that additional factors, such as total alkalinity (Mari, 2008; Passow, 2012) or nutrient stoichiometry (Corzo et al., 2000; Staats et al., 2000; Passow, 2002; Beauvais et al., 2006), should be considered in future experiments that investigate TEP aggregation (Passow and Carlson, 2012). Synergistic effects of increased temperature and OA on microbial community composition (Lindh et al., 2012), and OA and increased inorganic nutrients on bacterial production (Baltar et al., 2013) have also been found. It is therefore crucial to move towards a multiple-factor approach in the design of mesocosm experiments to better constrain the effect of multiple environmental drivers on the MCP and the BP. However, studying the impact of multiple factors demands a more complex experimental design and statistical approach to distinguish between subtle and interacting effects (Breitburg et al., 1998). Oceanographers would benefit from the experience of multiple stressor studies undertaken in freshwater and terrestrial environments by ecotoxicologists to develop hypotheses and concepts linking global, regional and local anthropogenic drivers and their combined effects on ocean biota (Calow, 1989; Boyd and Hutchins, 2012).

In situ mesoscale addition experiments where a single water mass tagged with the inert tracer sulfur hexafluoride along with a potentially limiting nutrient (e.g., iron) or nutrients (e.g., iron and phosphate) (Boyd et al., 2007) could also be adapted for the study of the BP and MCP. The unequivocal lagrangian sampling mode which this allows could be used to study the effect of changing DOC concentration and composition associated with for example whale or zooplankton excretion, melting sea-ice, increased river flow or the offshore movement of upwelled water (Loucaides et al., 2012).

\subsection{Improved chemical analytical and genomic approaches}

Lipid biomarkers and their carbon isotopes can be powerful tools for identification of the microorganisms participating in POM and DOM cycling (White et al., 1979; Zhang et al., 2002), which may also help link biogeochemical processes in the water column and sediments. The concentrations of ester-linked phospholipid fatty acids (PLFA) and intact polar Archaeal lipids (IPAL) indicate the biomasses of extant bacteria and Archaea, respectively, in complex ecosystems (White et al., 1979; Zhang et al., 2002; Sturt et al., 2004; Lipp et al., 2008; Liu et al., 2011). Furthermore, certain lipids can be used as biomarkers because they are characteristic of, or unique to, certain microbes. Such lipid biomarkers or their combinations can reflect community structure, physiological and nutritional status, and the dynamic biogeochemical processes carried out by the microbes (White et al., 1998; Suzumura, 2005). In addition, the carbon isotopes of lipid biomarkers can be used as tracers for molecular level flow of carbon and thus serve to evaluate the efficiency of the MCP and quantify its relationship with the BP because the products of BP-based organisms may serve as the substrates of MCP-based organisms.

Radiocarbon is another powerful approach for quantification of MCP or BP activities in the ocean. From POC to DIC to DOC, the ${ }^{14} \mathrm{C}$ values decrease sequentially. If the BP plays a dominant role in the ocean, a more ${ }^{14} \mathrm{C}$ positive signature would be seen in the water column and sediment organic carbon; on the other hand, if MCP dominates, the reworking of POC in the water column may shift organic carbon toward older DOC with depleted ${ }^{14} \mathrm{C}$ (McNichol and Aluwihare, 2007). The ${ }^{14} \mathrm{C}$ of lipid biomarkers can help to evaluate pathways of carbon metabolism by deep-ocean microbes. For example, the ${ }^{14} \mathrm{C}$ values of glycerol dialkyl glycerol tetraethers from deep sea ammonia-oxidizing Archaea are closer to the ${ }^{14} \mathrm{C}$ value of DIC, indicating that these organisms fix $\mathrm{CO}_{2}$ in the deep ocean (Ingalls et al., 2006). Such an approach would help evaluate the autotrophic versus heterotrophic capabilities of meso- and bathypelagic prokaryotes. Studying the ${ }^{14} \mathrm{C}$ signature of DNA collected from mesopelagic Pacific waters, Hansman et al. (2009) concluded that both DIC and fresh DOC (presumably released from sinking POC) are utilized, while ambient DOC is not a major substrate.

What is more challenging is linking the taxonomic composition of microbial communities with their possible functions in the carbon cycle. In particular, it is not clear if the biological formation of RDOC is carried out by all microbes or by a subset of the microbial community. New sequencing technology has been instrumental in the 
proliferation of genomic approaches for exploring potential metabolisms and biogeochemical roles of microbes in the oceans. These approaches include metagenomic and metatranscriptomic methods, which are based on the direct sequencing of genomes and transcripts from all organisms in a particular size class (usually the one dominated by bacteria and Archaea) without isolation or separation of individual taxa (Moran, 2008; Kirchman, 2012). These methods give insights into the potential function of microbes and have suggested new pathways, such as light-harvesting by proteorhodopsin (Béjà et al., 2000) in the open oceans. Data from genomic sequencing of single cells isolated by flow cytometry have suggested metabolisms, such as chemolithotrophy based on sulfur oxidation in mesopelagic waters (Swan et al., 2011).

These "omic" approaches have provided insights into processes involving labile DOC (Poretsky et al., 2010), but work is needed to get a complete picture of how microbes interact with all DOC components in the oceans. Microbial oceanographers face several challenges in using omic approaches to explore DOC use and formation. One challenge is that analysis of sequence data heavily depends on databases of sequences from laboratory-grown organisms with known metabolic functions. These laboratory-grown organisms may not be representative of uncultivated oceanic microbes. Another problem is that not all of the genes in even heavily studied organisms, such as Escherichia coli, are completely known, and typically 10-20\% of a prokaryotic genome will not be similar to genes from any organism (Koonin and Wolf, 2008). Even when identified by its similarity to known genes, more detailed enzymatic analysis may not show the predicted function (Cottrell et al., 2005). Consequently, there are problems in using genomic information to examine even known functions. It is even more difficult to use genomic data to gain insights into processes such as RDOC formation when the basic biogeochemical mechanisms are unknown.

It is unlikely that a single gene or gene cluster will provide the answer to RDOC formation, just as few diseases can be traced to defects in one or two genes. However, genomes represent the evolutionary record of how microbes have interacted with DOC over millennia. If we can read that record, we are likely to learn much about DOC-microbe interactions. Coupling omic studies with geochemical studies on all DOC components is likely to give new insights into the MCP.

\subsection{Ecosystem modeling}

Biogeochemical models have been used to study DOC cycling and its interactions with heterotrophic prokaryotes in the surface ocean, indicating that oligotrophic conditions can lead to the accumulation and export of semi-labile DOC (SLDOC, a fraction of DOC, which resides mainly in the upper layer but becomes labile when transported to deep water) (Polimene et al., 2006; Luo et al., 2010). To better understand carbon sequestration, further modeling studies are required

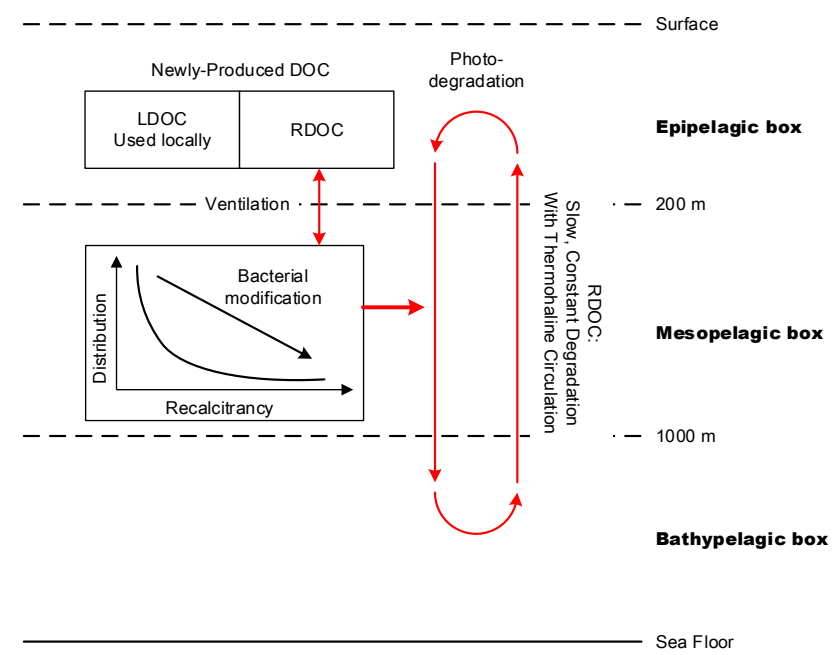

Figure 7. A conceptual framework for ecosystem modeling.

to quantify the relative importance of the MCP and BP, identify processes which contribute the greatest uncertainties in their quantification, and guide the priorities for future field and laboratory work.

The key processes to be represented in an MCP model are those that describe the production and removal of RDOC in different vertical regimes. An initial step could be to set up a conceptual model representing the ocean as simply three vertical boxes: the epipelagic (surface $200 \mathrm{~m}$ ), mesopelagic (200 to $1000 \mathrm{~m}$ ) and bathypelagic zones (below $1000 \mathrm{~m}$ ) (Fig. 7). In the epipelagic zone, such a model would focus on quantifying the production of SLDOC. The model of Flynn et al. (2008) provides a basis for such work, describing the production of different types of DOM as a function of the growth and nutrient status of primary producers. Similar models are needed for DOM production by zooplankton, and for the consumption of all fractions of DOM by bacteria and other microbes. The proposal made by Mitra et al. (2014) places an additional reason to develop these simulations, with mixotrophs simultaneously producing DOM through phototrophy and phagotrophy, while consuming bacteria whose growth is supported by the same DOM.

In the mesopelagic zone, the model would need to address the lability continuum of RDOC. A mechanism would be needed to determine a flexible lability continuum according to the nutrient conditions in the overlying epipelagic layer: the continuum would move toward recalcitrance in oligotrophic oceans while being more labile in eutrophic regions (Jiao and Zheng, 2011). Such a model could also include a description of processes in the mesopelagic layer allowing the modification of the accessibility of RDOC to heterotrophic bacteria. This requires the development of a model which describes the ability of bacteria to discriminate between different types of DOM with changes in stoichiometry $(\mathrm{C}: \mathrm{N}: \mathrm{P})$, and which can reflect changes in growth rates, 
growth efficiency and respiration. While such models exist (e.g., Flynn, 2005; Luo et al., 2010), other than for use in conceptualized scenarios, all these models remain largely empirical because of the practical challenges surrounding the characterization and quantification of different DOM fractions.

Accepting that limitation, assuming that the DOC concentration in the bathypelagic zone does not change substantially with depth (Hansell, 2013), the model can address the suggestion that RDOC is not directly transported to local bathypelagic zones, but moves with the thermohaline circulation and is degraded slowly within all three vertical layers. This initial model simulates $\mathrm{CO}_{2}$ production as the result of degrading RDOC in different vertical layers. Together with an estimation of deep water ventilation and exchange rates of water masses between the three vertical boxes, it is expected to quantify the role of the MCP in carbon sequestration on various timescales (Fig. 7).

Models of these processes within coastal ocean scenarios will help in evaluating anthropogenic impacts on carbon sequestration by both the BP and the MCP. In silico experiments could be set up with different rates and stoichiometries of riverine nutrient inputs. Carbon sequestration resulting from the BP in coastal oceans also needs to consider the remineralization of POC in subsurface layers, as well as the resuspension of benthic POC; however, while models may clearly differentiate between POC and DOC, in real world sampling the so-called DOC fraction is contaminated by micro-particulates (i.e., POC) that compounds the already challenging definition of labile, semi-labile and refractory fractions. Here, perhaps more than for ocean systems, it is necessary to describe the variable stoichiometry of the DOM fractions. To quantify carbon sequestration by the MCP, parameters which control both DOC lability and its interactions with bacteria should be described in the model. To further quantify the fate of DOC after use by bacteria, variable stoichiometry for bacterial cellular composition is required. The model ultimately needs to calculate the net rate of supply of RDOC to the adjacent open ocean and thus give estimates for the net carbon sequestration rate by the MCP.

These model experiments could be used to determine a relationship between carbon sequestration (from the BP and the $\mathrm{MCP}$ ) and the nutrient input from rivers, in order to estimate an optimal rate and stoichiometry of riverine nutrient input for maximum carbon sequestration. Reverse modeling methods (Friedrichs et al., 2007; Luo et al., 2010), may be applied to improve these estimates, and to unveil the uncertainties associated with model processes and parameters.

Modeling of ocean ecosystems has relied heavily on the concept of functional groups, with more complex models having multiple functional types within each modeled group. For example, the singular phytoplankton box of early nutrient-phytoplankton-zooplankton-detritus (NPZD) models has been extended to take account of size (e.g., pico, nano and micro size classes), biogeochemical function (e.g., silicifiers, calcifiers, dimethylsulfide producers, Le Quere et al.,
2005) or taxonomy (e.g., diatoms, dinoflagellates, Blackford et al., 2004). While understanding of microbial heterotrophic communities in the ocean is advancing rapidly, there is no clear differentiation of a set of bacterial and Archaeal functional types. As with other marine ecosystem modeling approaches, the resolution and descriptions used will vary according to the question posed. For example, taxonomically it may be desirable to separate Archaea from bacteria, whereas in the context of understanding biogeochemical transformations of POC and RDOC, it may be more opportune to model the affinities of organisms to different substrates (particles, gels or DOC) or their evolutionary strategies for responding to different resource environments. In this regard, partitioning into copiotrophs that use chemotaxis, motility and fast uptake kinetics to exploit microscale gradients of high nutrient concentration, versus non-motile oligotrophs that are adapted to life in nutrient poor environments (Stocker, 2012) may provide a good starting point.

Modeling studies would eventually need to extend to the global scale, aiming to reproduce the distribution of DOC and predict how the MCP and BP will change with changing anthropogenic influences. Overall, two-way interaction should be maintained between the MCP-BP modeling and observational scientific communities: the results from experiments will help parameterize the model, and model results will then guide further experimentation. First and foremost, however, is the need to rationalize the chemical, biological and modeling descriptions of different types of DOM.

\subsection{Strategies to enhance carbon sequestration}

Based on the discussion above (Sect. 5.2, Fig. 4) and a statistical study which shows that concentrations of organic carbon and nitrate in natural environments ranging from soils and rivers, to coastal and oceanic waters are inversely correlated (Taylor and Townsend, 2010), it seems that if we want to store more organic carbon in the environment we must avoid high concentrations of nutrients. Therefore, reduced nutrient levels in otherwise eutrophic coastal waters could result in a greater proportion of the fixed carbon becoming RDOC (or $\mathrm{RDOC}_{\mathrm{t}}$ ) (Jiao et al., 2010b). Then we may be able to enhance carbon sequestration in the coastal zone by controlling the discharge of nutrients from land. This can be achieved through the integrative management of the landocean system, for example by using methods of fertilization which avoid loss of nutrients to rivers and reducing sewage discharge to coastal waters. Such an integrative management approach would have the additional advantage of reducing eutrophication. Furthermore, the carbon storage capacity of coastal regions could be enhanced by optimizing both the BP and the MCP (Fig. 4). If the key to the efficiency of carbon storage in an ecosystem is the nutrient status, then it is critical to perform field-based research to fully understand the tipping point of the nutrient concentration or stoichiometry that leads to different types of carbon metabolism. An "optimal 
nutrient concentration/stoichiometry" could be obtained for a given ecosystem through theoretical calculation and field experimentation.

\section{Summary}

This synthesis of current research and gaps in our knowledge leads to the following conclusions and suggestions for future research:

RDOC can be classified as $\mathrm{RDOC}_{\mathrm{t}}$ and $\mathrm{RDOC}_{\mathrm{c}}$ depending on the composition and concentration of the RDOC molecules as well as the prevailing environmental conditions. State-of-the-art analytical chemical and genomic methods should be used to determine the microbial source and composition of RDOC and assess the environmental conditions which influence the recalcitrance of RDOC.

Analyses of biomarkers and isotopic records show intensive MCP processes in the Proterozoic oceans when the MCP could have played a more significant role in regulating climate. Understanding MCP dynamics in the past will aid in predicting how carbon storage could change with changing climatic conditions in the future.

Future research programs should integrate the study of POC flux and DOC transformation in order to elucidate the interactions between POC and DOC cycling and the environmental controls on these interactions. This includes an investigation of the occurrence and lability of RDOC-coated POC.

Bioassay and field experiments should be undertaken to assess the combined effects of multiple environmental drivers (temperature, OA and nutrient supply) on marine carbon storage. Ecosystem models need to be developed and tested with mechanistic relationships derived from these experiments in order to predict the dynamics of and interactions between the BP and the MCP under global change scenarios including changing mixing and circulation, changing nutrient and oxygen distributions, and increasing temperature and decreasing $\mathrm{pH}$.

We hypothesize that increased nutrient supply to an ecosystem above a tipping point will decrease the efficiency of carbon storage by the MCP and in the long term by the BP as well. If supported, this could have important implications for management strategies for carbon sequestration and coastal ecosystem health including reduced eutrophication and hypoxia.

Acknowledgements. We thank the organisers, sponsors and participants of the IMBIZO III workshop. Particular thanks go to our hosts at the National Institute of Oceanography, Goa, India, and the staff of the IMBER International Project Office, Lisa Maddison, Bernard Avril and Liuming Hu. We acknowledge financial support from the MOST 973 program 2013CB955700, the NSFC projects 91028001, 91328209, 41376132 and 91028011, and the SOA projects 201105021 and GASI-03-01-02-05. FA was supported by a grant from the Gordon and Betty Moore Foundation Marine
Microbiology Initiative. A. Mitra was supported in part by project EURO-BASIN (ref. 264933, 7FP, European Union) and also by a Leverhulme International Networking Grant.

Edited by: G. Herndl

\section{References}

Allgaier, M., Riebesell, U., Vogt, M., Thyrhaug, R., and Grossart, H.-P.: Coupling of heterotrophic bacteria to phytoplankton bloom development at different $p \mathrm{CO}_{2}$ levels: a mesocosm study, Biogeosciences, 5, 1007-1022, doi:10.5194/bg-5-10072008, 2008.

Alonso-González, I. J., Arístegui, J., Lee, C., and Calafat, A.: Regional and temporal variability of sinking organic matter in the subtropical northeast Atlantic Ocean: a biomarker diagnosis, Biogeosciences, 7, 2101-2115, doi:10.5194/bg-7-21012010, 2010.

Anderson, T. R. and Tang, K. W.: Carbon cycling and POC turnover in the mesopelagic zone of the ocean: Insights from a simple model, Deep-Sea Res. Pt. II., 57, 1581-1592, 2010.

Arístegui, J. and Montero, M. F.: Temporal and spatial changes in plankton respiration and biomass in the Canary Islands region: the effect of mesoscale variability, J. Marine. Syst., 54, 65-82, 2005.

Arístegui, J., Tett, P., Hernández-Guerra, A., Basterretxea, G., Montero, M. F., Wild, K., Sangrá, P., Hernández-León, S., Cantón, M., García-Braun, J. A., Pacheco, M., and Barton, E. D.: The influence of island-generated eddies on chlorophyll distribution: a study of mesoscale variation around Gran Canaria, Deep-Sea Res., 44, 71-96, 1997.

Arístegui, J., Gasol, J. M., Duarte, C. M., and Herndl, G. J.: Microbial Oceanography of the dark ocean's pelagic realm, Limnol Oceanogr., 54, 1501-1529, 2009.

Arnosti, C.: Microbial Extracellular Enzymes and the Marine Carbon Cycle, Ann. Rev. Mar. Sci., 3, 401-425, 2011.

Arnosti, C., Fuchs, B. M., Amann, R., and Passow, U.: Contrasting extracellular enzyme activities of particle-associated bacteria from distinct provinces of the North Atlantic Ocean, Front. Microbiol., 3, 425, doi:10.3389/fmicb.2012.00425, 2012.

Azam, F. and Malfatti, F.: Microbial structuring of marine ecosystems, Nat. Rev. Microbiol., 5, 782-791, 2007.

Baldock, J. A., Masiello, C. A., Gelinas, Y., and Hedges, J. I.: Cycling and composition of organic matter in terrestrial and marine ecosystems, Mar. Chem., 92, 39-64, 2004.

Baltar, F., Arístegui, J., Gasol, J. M., Hernández-León, S., and Herndl, G. J.: Strong coast - ocean and surface - depthgradients in prokaryotic assemblage structure and activity in a coastal transition zone region, Aquat. Microb. Ecol., 50, 63-74, 2007.

Baltar, F., Arístegui, J., Gasol, J. M., Sintes, E., and Herndl, G. J.: Evidence of prokaryotic metabolism on suspended particulate organic matter in the dark waters of the subtropical North Atlantic, Limnol. Oceanogr., 54, 182-193, 2009.

Baltar, F., Arístegui, J., Gasol, J. M., Lekunberri, I., and Herndl, G. J.: Mesoscale eddies: Hotspots of prokaryotic activity and differential community structure in the ocean, ISME J., 4, 975-988, 2010a.

Baltar, F., Arístegui, J., Gasol, J. M., Sintes, E., van Aken, H. M., and Herndl, G. J.: High dissolved extracellular enzymatic activ- 
ity in the deep central Atlantic Ocean, Aquat. Microb. Ecol., 58, 287-302, 2010b.

Baltar, F., Palovaara, J., Vila-Costa, M., Calvo, E., Pelejero, C., Marrase, C., Salazar, G., Gasol, J. M., and Pinhassi, J.: Response of rare versus abundant bacterioplankton to disturbances in a Mediterranean coastal site, in 13th Symposium on Aquatic microbial Ecology, Stresa, Italy, 8-13 September 2013, 2013.

Barber, R. T.: Dissolved organic carbon from deep waters resists microbial oxidation, Nature, 220, 274-275, 1968.

Barker, S., Higgins, J. A., and Elderfield, H.: The future of the carbon cycle: review, calcification response, ballast and feedback on atmospheric $\mathrm{CO}_{2}$, Philos. Trans. A Math. Phys. Eng. Sci., 361, 1977-1999, 2003.

Bauer, J. E., Williams, P. M., and Druffel, E. R. M.: ${ }^{14} \mathrm{C}$ activity of dissolved organic carbon fractions in the north-central Pacific and Sargasso Sea, Nature, 357, 667-670, 1992.

Beauvais, S., Pedrotti, M. L., Egge, J., Iversen, K., and Marrasé, C.: Effects of turbulence on TEP dynamics under contrasting nutrient conditions: implications for aggregation and sedimentation processes, Mar. Ecol.-Prog. Ser., 323, 47-57, 2006.

Béjà, O., Aravind, L., Koonin, E. V., Suzuki, M. T., Hadd, A., Nguyen, L. P., Jovanovich, S., Gates, C. M., Feldman, R. A., Spudich, J. L., Spudich, E. N., and DeLong, E. F.: Bacterial rhodopsin: Evidence for a new type of phototrophy in the sea, Science, 289, 1902-1906, 2000.

Bhaskar, P. V. and Bhosle, N. B.: Microbial extracellular polymeric substances in marine biogeochemical processes, Curr. Sci. India, 88, 45-53, 2005.

Bidigare, R. R., Chai, F., Landry, M. R., Lukas, R., Hannides, C. C. S., Christensen, S. J., Karl, D. M., Shi, L., and Chao, Y.: Subtropical ocean ecosystem structure changes forced by North Pacific climate variations, J. Plankton. Res., 31, 1131-1139, 2009.

Blackford, J. C., Allen, J. I., and Gilbert, F. J.: Ecosystem dynamics at six contrasting sites: a generic modelling study, J. Marine. Syst., 52, 191-215, 2004.

Bode, A., Barquero, S., Varela, M., Braun, J. A., and de Armas, D.: Pelagic bacteria and phytoplankton in oceanic waters near the Canary Islands in summer, Mar. Ecol.-Prog. Ser., 209, 1-17, 2001

Boyd, P. W. and Hutchins, D. A.: Understanding the responses of ocean biota to a complex matrix of cumulative anthropogenic change, Mar. Ecol.-Prog. Ser., 470, 125-135, 2012.

Boyd, P. W., Jickells, T., Law, C. S., Blain, S., Boyle, E. A., Buesseler, K. O., Coale, K. H., Cullen, J. J., de Baar, H. J. W., Follows, M., Harvey, M., Lancelot, C., Levasseur, M., Owens, N. P. J., Pollard, R., Rivkin, R. B., Sarmiento, J., Schoemann, V., Smetacek, V., Takeda, S., Tsuda, A., Turner, S., and Watson, A. J.: Mesoscale iron enrichment experiments 1993-2005: Synthesis and future directions, Science, 315, 612-617, 2007.

Breitburg, D. L., Baxter, J. W., Hatfield, C. A., Howarth, R. W., Jones, C. G., Lovett, G. M., and Wigand, C.: Understanding effects of multiple stressors: ideas and challenges, in: Successes, Limitations, and Frontiers in ecosystem science, edited by: Pace, M. L., and Groffman, P. M., Springer-Verlag New York, Inc., New York, 416-431, 1998.

Brewin, R. J. W., Lavender, S. J., Hardman-Mountford, N. J., and Hirata, T.: A spectral response approach for detecting dominant phytoplankton size class from satellite remote sensing, Acta Oceanol. Sin., 29, 14-32, 2010a.
Brewin, R. J. W., Sathyendranath, S., Hirata, T., Lavender, S. J., Barciela, R. M., and Hardman-Mountford, N. J.: A threecomponent model of phytoplankton size class for the Atlantic Ocean, Ecol. Model., 221, 1472-1483, 2010 b.

Brophy, J. E. and Carlson, D. J.: Production of biologically refractory dissolved organic carbon by natural seawater microbial populations, Deep-Sea. Res. Pt. I., 36, 497-507, 1989.

Brussaard, C. P. D., Noordeloos, A. A. M., Witte, H., Collenteur, M. C. J., Schulz, K., Ludwig, A., and Riebesell, U.: Arctic microbial community dynamics influenced by elevated $\mathrm{CO}_{2}$ levels, Biogeosciences, 10, 719-731, doi:10.5194/bg-10-719-2013, 2013.

Calow, P.: Proximate and ultimate responses to stress in biological systems, Biol. J. Linn. Soc., 37, 173-181, 1989.

Canfield, D. E. and Kump, L. R.: Geochemistry, Carbon cycle makeover, Science, 339, 533-534, 2013.

Capotondi, A., Alexander, M. A., Bond, N. A., Curchitser, E. N., and Scott, J. D.: Enhanced upper ocean stratification with climate change in the CMIP3 models, J. Geophys. Res., 117, C04031, doi:10.1029/2011jc007409, 2012.

Carder, K. L., Steward, R. G., and Betzer, P. R.: In situ holographic measurements of the sizes and settling rates of oceanic particulates, J. Geophys. Res., 87, 5681-5685, 1982.

Carlson, C. A., Giovannoni, S. J., Hansell, D. A., Goldberg, S. J., Parsons, R., Otero, M. P., Vergin, K., and Wheeler, B. R.: Effect of nutrient amendments on bacterioplankton production, community structure, and DOC utilization in the northwestern Sargasso Sea, Aquat. Microb. Ecol., 30, 19-36, 2002.

Carlson, C. A., Giovannoni, S. J., Hansell, D. A., Goldberg, S. J., Parsons, R., and Vergin, K.: Interactions among dissolved organic carbon, microbial processes, and community structure in the mesopelagic zone of the northwestern Sargasso Sea, Limnol. Oceanogr., 49, 1073-1083, 2004.

Carlson, C. A., Hansell, D. A., and Tamburini, C.: DOC Persistence and its Fate After Export Within the Ocean Interior, in: Microbial Carbon Pump in the Ocean, edited by: Jiao, N., Azam, F., and Sanders, S., Science/AAAS Business Office, Washington, DC, 57-59, 2011.

Cheney, R. E. and Richardson, P. L.: Observed decay of a cyclonic Gulf Stream ring, Deep-Sea Res., 23, 143-155, 1976.

Ciotti, A. M. and Bricaud, A.: Retrievals of a size parameter for phytoplankton and spectral light absorption by colored detrital matter from water-leaving radiances at SeaWiFS channels in a continental shelf region off Brazil, Limnol. Oceanogr.-Meth., 4, 237-253, 2006.

Corzo, A., Morillo, J. A., and Rodríguez, S.: Production of transparent exopolymer particles (TEP) in cultures of Chaetoceros calcitrans under nitrogen limitation, Aquat. Microb. Ecol., 23, 63-72, 2000.

Costerton, J. W., Lewandowski, Z., Caldwell, D. E., Korber, D. R., and Lappinscott, H. M.: Microbial Biofilms, Annu. Rev. Microbiol., 49, 711-745, 1995.

Cottrell, M. T., Yu, L., and Kirchman, D. L.: Sequence and expression analyses of Cytophaga-like hydrolases in a western Arctic metagenomic library and the Sargasso Sea, Appl. Environ. Microbiol., 71, 8506-8513, 2005.

Craig, S. E., Thomas, H., Jones, C. T., Li, W. K. W., Greenan, B. J. W., Shadwick, E. H., and Burt, W. J.: Temperature and phytoplankton cell size regulate carbon uptake and carbon over- 
consumption in the ocean, Biogeosciences Discuss., 10, 1125511282, doi:10.5194/bgd-10-11255-2013, 2013.

Dall'Olmo, G., Westberry, T. K., Behrenfeld, M. J., Boss, E., and Slade, W. H.: Significant contribution of large particles to optical backscattering in the open ocean, Biogeosciences, 6, 947-967, doi:10.5194/bg-6-947-2009, 2009.

Dang, H. and Jiao, N.: Perspectives on the microbial carbon pump with special reference to microbial respiration and ecosystem efficiency in large estuarine systems, Biogeosciences, 11, 38873898, doi:10.5194/bg-11-3887-2014, 2014.

DeLong, E. F., Preston, C. M., Mincer, T., Rich, V., Hallam, S. J., Frigaard, N. U., Martinez, A., Sullivan, M. B., Edwards, R., Brito, B. R., Chisholm, S. W., and Karl, D. M.: Community genomics among stratified microbial assemblages in the ocean's interior, Science, 311, 496-503, 2006.

Devred, E., Sathyendranath, S., Stuart, V., and Platt, T.: A three component classification of phytoplankton absorption spectra: Application to ocean-color data, Remote Sens. Environ., 115, 2255-2266, 2011.

Doney, S. C.: Oceanography: Plankton in a warmer world, Nature, 444, 695-696, 2006.

Doney, S. C., Fabry, V. J., Feely, R. A., and Kleypas, J. A.: Ocean acidification: the other $\mathrm{CO}_{2}$ problem, Annu. Rev. Mar. Sci., 1, 169-192, 2009.

Druffel, E. R. M. and Williams, P. M.: Identification of a deep marine source of particulate organic-carbon using bomb C-14, Nature, 347, 172-174, 1990.

Egge, J. K., Thingstad, T. F., Larsen, A., Engel, A., Wohlers, J., Bellerby, R. G. J., and Riebesell, U.: Primary production during nutrient-induced blooms at elevated $\mathrm{CO}_{2}$ concentrations, Biogeosciences, 6, 877-885, doi:10.5194/bg-6-877-2009, 2009.

Emeis, K.-C., Beusekom, J. V., Callies, U., Ebinghaus, R., Kannen, A., Kraus, G., Kröncke, I., Lenhart, H., Lorkowski, I., Matthias, V., Möllmann, C., Pätsch, J., Scharfe, M., Thomas, H., Weisse, R., and Zorita, E.: The North Sea - a shelf sea in the anthropocene, J. Marine Syst., IMBIZO special issue, doi:10.1016/j.jmarsys.2014.03.012, in press, 2014.

Engel, A.: Direct relationship between $\mathrm{CO}_{2}$ uptake and transparent exopolymer particles production in natural phytoplankton, $\mathrm{J}$. Plankton. Res., 24, 49-53, 2002.

Engel, A., Delille, B., Jacquet, S., Riebesell, U., Rochelle-Newall, E., Terbrüggen, A., and Zondervan, I.: Transparent exopolymer particles and dissolved organic carbon production by Emiliania huxleyi exposed to different $\mathrm{CO}_{2}$ concentrations: a mesocosm experiment, Aquat. Microb. Ecol., 34, 93-104, 2004a.

Engel, A., Thoms, S., Riebesell, U., Rochelle-Newall, E., and Zondervan, I.: Polysaccharide aggregation as a potential sink of marine dissolved organic carbon, Nature, 428, 929-932, 2004b.

Falkowski, P. G., Ziemann, D. A., Kolber, D. A., and Bienfang, P. K.: Role of eddy pumping in enhancing primary production in the ocean, Nature, 352, 55-58, 1991.

Fike, D. A., Grotzinger, J. P., Pratt, L. M., and Summons, R. E.: Oxidation of the Ediacaran ocean, Nature, 444, 744-747, 2006.

Flerus, R., Lechtenfeld, O. J., Koch, B. P., McCallister, S. L., Schmitt-Kopplin, P., Benner, R., Kaiser, K., and Kattner, G.: A molecular perspective on the ageing of marine dissolved organic matter, Biogeosciences, 9, 1935-1955, doi:10.5194/bg-9-19352012, 2012.
Flynn, K. J.: Incorporating plankton respiration in models of aquatic ecosystem function, in: Respiration in Aquatic Ecosystems, edited by: Giorgio, P. A. D. and Williams, P. J. L. B., Oxford University Press, 2005.

Flynn, K. J., Clark, D. R., and Xue, Y.: Modeling the release of dissolved organic matter by phytoplankton, J. Phycol., 44, 11711187, 2008.

Friedrichs, M. A. M., Dusenberry, J. A., Anderson, L. A., Armstrong, R. A., Chai, F., Christian, J. R., Doney, S. C., Dunne, J., Fujii, M., Hood, R., McGillicuddy, D. J., Moore, J. K., Schartau, M., Spitz, Y. H., and Wiggert, J. D.: Assessment of skill and portability in regional marine biogeochemical models: Role of multiple planktonic groups, J. Geophys. Res., 112, C08001, doi:10.1029/2006jc003852, 2007.

Fu, F. X., Warner, M. E., Zhang, Y., Feng, Y., and Hutchins, D. A.: Effects of increased temperature and $\mathrm{CO}_{2}$ on photosynthesis, growth, and elemental ratios in marine Synechococcus and Prochlorococcus (Cyanobacteria), J. Phycol., 43, 485-496, 2007.

Fuhrman, J. A.: Close Coupling between Release and Uptake of Dissolved Free Amino-Acids in Seawater Studied by an IsotopeDilution Approach, Mar. Ecol.-Prog. Ser., 37, 45-52, 1987.

Gardner, W. D., Mishonov, A., and Richardson, M. J.: Global POC concentrations from in-situ and satellite data, Deep-Sea Res. Pt. II., 53, 718-740, 2006.

Gasol, J. M., Vázquez-Domínguez, E., Vaqué, D., Agustí, S., and Duarte, C. M.: Bacterial activity and diffusive nutrient supply in the oligotrophic Central Atlantic Ocean, Aquat. Microb. Ecol., 56, 1-12, 2009.

Gonsior, M., Peake, B. M., Cooper, W. T., Podgorski, D., D'Andrilli, J., and Cooper, W. J.: Photochemically Induced Changes in Dissolved Organic Matter Identified by Ultrahigh Resolution Fourier Transform Ion Cyclotron Resonance Mass Spectrometry, Environ. Sci. Technol., 43, 698-703, 2009.

Grimsditch, G., Alder, J., Nakamura, T., Kenchington, R., and Tamelander, J.: The blue carbon special edition - Introduction and overview, Ocean. Coast. Manage., 83, 1-4, 2013.

Grossart, H. P., Allgaier, M., Passow, U., and Riebesell, U.: Testing the effect of $\mathrm{CO}_{2}$ concentration on the dynamics of marine heterotrophic bacterioplankton, Limnol. Oceanogr., 51, 1-11, 2006.

Grotzinger, J. P., Fike, D. A., and Fischer, W. W.: Enigmatic origin of the largest-known carbon isotope excursion in Earth's history, Nat. Geosci., 4, 285-292, 2011.

Gruber, D. F., Simjouw, J. P., Seitzinger, S. P., and Taghon, G. L.: Dynamics and characterization of refractory dissolved organic matter produced by a pure bacterial culture in an experimental predator-prey system, Appl. Environ. Microb., 72, 4184-4191, 2006.

Hansell, D. A.: Recalcitrant Dissolved Organic Carbon Fractions, Annu. Rev. Mar. Sci., 5, 421-445, 2013.

Hansell, D. A., Carlson, C. A., Repeta, D. J., and Schlitzer, R.: Dissolved organic matter in the ocean - A controversy stimulates new insights, Oceanography, 22, 202-211, 2009.

Hansell, D. A., Carlson, C. A., and Schlitzer, R.: Net removal of major marine dissolved organic carbon fractions in the subsurface ocean, Global. Biogeochem. Cy., 26, GB1016, doi:10.1029/2011gb004069, 2012.

Hansman, R. L., Griffin, S., Watson, J. T., Druffel, E. R. M., and Ingalls, A. E.: The radiocarbon signature of microorganisms in the 
mesopelagic ocean, P. Natl. Acad. Sci. USA, 106, 6513-6518, 2009.

Harris, R. P., Boyd, P., Harbour, D. S., Head, R. N., Pingree, R. D., and Pomroy, A. J.: Physical, chemical and biological features of a cyclonic eddy in the region of $61^{\circ} 10^{\prime} \mathrm{N} 19^{\circ} 50^{\prime} \mathrm{W}$ in the North Atlantic., Deep-Sea Res. Pt. I, 11, 1815-1839, 1997.

Hartmann, M., Grob, C., Tarran, G. A., Martin, A. P., Burkill, P. H., Scanlan, D. J., and Zubkov, M. V.: Mixotrophic basis of Atlantic oligotrophic ecosystems, P. Natl. Acad. Sci. USA, 109, 57565760, 2012.

Hays, G. C., Richardson A. J., and Robinson C. Climate change and marine plankton, Trend. Ecol. Evol., 20, 337-244, 2005

Hedges, I. J. and Keil, R. G.: Sedimentary organic matter preservation: an assessment and speculative synthesis, Mar. Chem., 49, 81-115, 1995.

Henson, S. A., Sanders, R., and Madsen, E.: Global patterns in efficiency of particulate organic carbon export and transfer to the deep ocean, Global. Biogeochem. Cy., 26, GB1028, doi:10.1029/2011gb004099, 2012.

Hertkorn, N., Benner, R., Frommberger, M., Schmitt-Kopplin, P., Witt, M., Kaiser, K., Kettrup, A., and Hedges, J. I.: Characterization of a major refractory component of marine dissolved organic matter, Geochim. Cosmochim. Ac., 70, 2990-3010, 2006.

Hinder, S. L., Manning, J. E., Gravenor, M. B., Edwards, M., Walne, A. W., Burkill, P. H., and Hays, G. C.: Long-term changes in abundance and distribution of microzooplankton in the NE Atlantic and North Sea, J. Plankton. Res., 34, 83-91, 2012.

Hirata, T., Aiken, J., Hardman-Mountford, N., Smyth, T. J., and Barlow, R. G.: An absorption model to determine phytoplankton size classes from satellite ocean colour, Remote Sens. Environ., 112, 3153-3159, 2008a.

Hirata, T., Hardman-Mountford, N. J., Aiken, J., Martinez-Vicente, V., Fishwick, J., and Bernard, S.: Particle size distribution determined from ocean colour as a descriptor of nano/micro phytoplankton community in the oceans, in Proceedings of the Remote Sensing and Photogrammetry Society Conference 2008, University of Exeter, Falmouth, UK, 15-17 September 2008, 155-156, 2008b.

Hirata, T., Hardman-Mountford, N. J., Brewin, R. J. W., Aiken, J., Barlow, R., Suzuki, K., Isada, T., Howell, E., Hashioka, T., Noguchi-Aita, M., and Yamanaka, Y.: Synoptic relationships between surface Chlorophyll- $a$ and diagnostic pigments specific to phytoplankton functional types, Biogeosciences, 8, 311-327, doi:10.5194/bg-8-311-2011, 2011.

Honjo, S., Manganini, S. J., Krishfield, R. A., and Francois, R.: Particulate organic carbon fluxes to the ocean interior and factors controlling the biological pump: A synthesis of global sediment trap programs since 1983, Prog. Oceanogr., 76, 217-285, 2008.

Hoppe, H.-G., Breithaupt, P., Walther, K., Koppe, R., Bleck, S., Sommer, U., and Jürgens, K.: Climate warming in winter affects the coupling between phytoplankton and bacteria during the spring bloom: a mesocosm study, Aquat. Microb. Ecol., 51, 105$115,2008$.

Hwang, J. and Druffel, E. R.: Lipid-like material as the source of the uncharacterized organic carbon in the ocean?, Science, 299, 881-884, 2003.

Ingalls, A. E., Shah, S. R., Hansman, R. L., Aluwihare, L. I., Santos, G. M., Druffel, E. R. M., and Pearson, A.: Quantifying archaeal community autotrophy in the mesopelagic ocean using natural radiocarbon, P. Natl. Acad. Sci. USA, 103, 6442-6447, 2006.

IPCC: Climate Change 2013: The Physical Science Basis. Working Group I Contribution to the Fifth Assessment Report of the Intergovernmental Panel on Climate Change, edited by: Stocker, T. F., Qin, D., Plattner, G., Tignor, M., Allen, S. K., Boschung, J., Nauel, A., Xia, Y., Bex, V., and Midgley, P. M., Cambridge University Press, Cambridge, United Kingdom and New York, NY, USA, 1535 pp., 2013.

Jannasch, H. W.: The Microbial Turnover of Carbon in the DeepSea Environment, in: Direct Ocean Disposal of Carbon Dioxide, edited by: Handa, N. and Ohsumi, T., Terra Scientific Publishing Company (TERRAPUB), Tokyo, 1-11, 1995.

Jiang, H. B., Kong, R. Q., and Xu, X. D.: The N-Acetylmuramic Acid 6-Phosphate Etherase Gene Promotes Growth and Cell Differentiation of Cyanobacteria under Light-Limiting Conditions, J. Bacteriol., 192, 2239-2245, 2010.

Jiao, N. and Zheng, Q.: The microbial carbon pump: from genes to ecosystems, Appl. Environ. Microbiol., 77, 7439-7444, 2011.

Jiao, N., Herndl, G. J., Hansell, D. A., Benner, R., Kattner, G., Wilhelm, S. W., Kirchman, D. L., Weinbauer, M. G., Luo, T., Chen, F., and Azam, F.: Microbial production of recalcitrant dissolved organic matter: long-term carbon storage in the global ocean, Nat. Rev. Microbiol., 8, 593-599, 2010a.

Jiao, N., Tang, K., Cai, H., and Mao, Y.: Increasing the microbial carbon sink in the sea by reducing chemical fertilization on the land, Nat. Rev. Microbiol., 9, 75-75, doi:10.1038/nrmicro2386c2, 2010b.

Jiao, N., Herndl, G. J., Hansell, D. A., Benner, R., Kattner, G., Wilhelm, S. W., Kirchman, D. L., Weinbauer, M. G., Luo, T., Chen, F., and Azam, F.: The microbial carbon pump and the oceanic recalcitrant dissolved organic matter pool, Nat. Rev. Microbiol., 9, 555-555, doi:10.1038/nrmicro2386-c5, 2011.

Jiao, N., Luo, T., Zhang, R., Yan, W., Lin, Y., Johnson, Z. I., Tian, J., Yuan, D., Yang, Q., Zheng, Q., Sun, J., Hu, D., and Wang, P.: Presence of Prochlorococcus in the aphotic waters of the western Pacific Ocean, Biogeosciences, 11, 2391-2400, doi:10.5194/bg11-2391-2014, 2014.

Johnson, K. S., Berelson, W. M., Boss, E. S., Chase, Z., Claustre, H., Emerson, S. R., Gruber, N., Kortzinger, A., Perry, M. J., and Riser, S. C.: Observing Biogeochemical Cycles at Global Scales with Profiling Floats and Gliders Prospects for a Global Array, Oceanography, 22, 216-225, 2009.

Johnson, M. T., Greenwood, N., Sivyer, D. B., Thomson, M., Reeve, A., Weston, K., and Jickells, T. D.: Characterising the seasonal cycle of dissolved organic nitrogen using Cefas SmartBuoy highresolution time-series samples from the southern North Sea, Biogeochemistry, 113, 23-36, 2013.

Jørgensen, N. O. G. and Middelboe, M.: Occurrence and bacterial cycling of D amino acid isomers in an estuarine environment, Biogeochemistry, 81, 77-94, 2006.

Kadouri, D., Jurkevitch, E., Okon, Y., and Castro-Sowinski, S.: Ecological and agricultural significance of bacterial polyhydroxyalkanoates, Crit. Rev. Microbiol., 31, 55-67, 2005.

Kattner, G., Simon, M., and Koch, B.: Molecular characterization of dissolved organic matter and constraints for prokaryotic utilization, in: Microbial Carbon Pump in the Ocean, edited by: Jiao, N., Azam, F., and Sanders, S., Science/AAAS, Washington DC, 60-61, 2011. 
Kieber, R. J., Zhou, X. L., and Mopper, K.: Formation of CarbonylCompounds from UV-Induced Photodegradation of Humic Substances in Natural-Waters - Fate of Riverine Carbon in the Sea, Limnol. Oceanogr., 35, 1503-1515, 1990.

Kim, J. M., Lee, K., Shin, K., Yang, E. J., Engel, A., Karl, D. M., and Kim, H. C.: Shifts in biogenic carbon flow from particulate to dissolved forms under high carbon dioxide and warm ocean conditions, Geophys. Res. Lett., 38, L08612, doi:10.1029/2011g1047346, 2011.

Kiorboe, T. and Jackson, G. A.: Marine snow, organic solute plumes, and optimal chemosensory behavior of bacteria, Limnol. Oceanogr., 46, 1309-1318, 2001.

Kirchman, D. L.: Processes in Microbial Ecology, Oxford University Press, Oxford, 312 pp., 2012.

Koch, B. P., Witt, M., Engbrodt, R., Dittmar, T., and Kattner, G.: Molecular formulae of marine and terrigenous dissolved organic matter detected by electrospray ionization Fourier transform ion cyclotron resonance mass spectrometry, Geochim. Cosmochim. Ac., 69, 3299-3308, 2005.

Koch, B. P., Kattner, G., Witt, M., and Passow, U.: Molecular insights into the microbial formation of marine dissolved organic matter: recalcitrant or labile?, Biogeosciences, 11, 4173-4190, doi:10.5194/bg-11-4173-2014, 2014.

Koonin, E. V. and Wolf, Y. I.: Genomics of bacteria and archaea: the emerging dynamic view of the prokaryotic world, Nucleic. Acids. Res., 36, 6688-6719, 2008.

Kostadinov, T. S., Siegel, D. A., and Maritorena, S.: Retrieval of the particle size distribution from satellite ocean color observations, J. Geophys. Res., 114, C09015, doi:10.1029/2009jc005303, 2009.

Kostadinov, T. S., Siegel, D. A., and Maritorena, S.: Global variability of phytoplankton functional types from space: assessment via the particle size distribution, Biogeosciences, 7, 3239-3257, doi:10.5194/bg-7-3239-2010, 2010.

Kriest, I., Khatiwala, S., and Oschlies, A.: Towards an assessment of simple global marine biogeochemical models of different complexity, Prog. Oceanogr., 86, 337-360, 2010.

Kujawinski, E. B.: The Impact of Microbial Metabolism on Marine Dissolved Organic Matter, Annu. Rev. Mar. Sci., 3, 567-599, 2011.

Kujawinski, E. B., Del Vecchio, R., Blough, N. V., Klein, G. C., and Marshall, A. G.: Probing molecular-level transformations of dissolved organic matter: insights on photochemical degradation and protozoan modification of DOM from electrospray ionization Fourier transform ion cyclotron resonance mass spectrometry, Mar. Chem., 92, 23-37, 2004.

Lampitt, R. S., Achterberg, E. P., Anderson, T. R., Hughes, J. A., Iglesias-Rodriguez, M. D., Kelly-Gerreyn, B. A., Lucas, M., Popova, E. E., Sanders, R., Shepherd, J. G., Smythe-Wright, D., and Yool, A.: Ocean fertilization: a potential means of geoengineering?, Philos. Trans. R. Soc. London A, 366, 3919-3945, 2008.

Lauro, F. M., McDougald, D., Thomas, T., Williams, T. J., Egan, S., Rice, S., DeMaere, M. Z., Ting, L., Ertan, H., Johnson, J., Ferriera, S., Lapidus, A., Anderson, I., Kyrpides, N., Munk, A. C., Detter, C., Han, C. S., Brown, M. V., Robb, F. T., Kjelleberg, S., and Cavicchioli, R.: The genomic basis of trophic strategy in marine bacteria, P. Natl. Acad. Sci. USA, 106, 15527-15533, 2009.
Le Quere, C., Harrison, S. P., Prentice, I. C., Buitenhuis, E. T., Aumont, O., Bopp, L., Claustre, H., Da Cunha, L. C., Geider, R., Giraud, X., Klaas, C., Kohfeld, K. E., Legendre, L., Manizza, M., Platt, T., Rivkin, R. B., Sathyendranath, S., Uitz, J., Watson, A. J., and Wolf-Gladrow, D.: Ecosystem dynamics based on plankton functional types for global ocean biogeochemistry models, Glob. Change. Biol., 11, 2016-2040, 2005.

Lechtenfeld, O. J., Kattner, G., Flerus, R., McCallister, S. L., Schmitt-Kopplin, P., and Koch, B. P.: Molecular transformation and degradation of refractory dissolved organic matter in the Atlantic and Southern Ocean, Geochim. Cosmochim. Ac., 126, 321-337, 2014.

Legendre, L. and Le Fèvre, J.: From individual plankton cells to pelagic marine ecosystems and to global biogeochemical cycles, in: Particle analysis in oceanography, edited by: Demers, S., Springer-Verlag, Berlin, 261-300, 1991.

Legendre, L. and Le Fèvre, J.: Microbial Food Webs and the Export of Biogenic Carbon in Oceans, Aquat. Microb. Ecol., 9, 69-77, 1995.

Legendre, L. and Rassoulzadegan, F.: Food-web mediated export of biogenic carbon in oceans: Hydrodynamic control, Mar. Ecol.Prog. Ser., 145, 179-193, 1996.

Li, C., Love, G. D., Lyons, T. W., Fike, D. A., Sessions, A. L., and Chu, X. L.: A Stratified Redox Model for the Ediacaran Ocean, Science, 328, 80-83, 2010.

Lindh, M. V., Riemann, L., Baltar, F., Romero-Oliva, C., Salomon, P. S., Granéli, E., and Pinhassi, J.: Consequences of increased temperature and acidification on bacterioplankton community composition during a mesocosm spring bloom in the Baltic Sea, Environ. Microbiol. Rep., 5, 252-262, 2012.

Lipp, J. S., Morono, Y., Inagaki, F., and Hinrichs, K. U.: Significant contribution of Archaea to extant biomass in marine subsurface sediments, Nature, 454, 991-994, 2008.

Liu, J., Jiao, N., and Tang, K.: An experimental study on the effects of nutrient enrichment on organic carbon persistence in the western Pacific oligotrophic gyre, Biogeosciences, 11, 5115-5122, doi:10.5194/bg-11-5115-2014, 2014.

Liu, Y., Yao, T., Jiao, N., Tian, L., Hu, A., Yu, W., and Li, S.: Microbial diversity in the snow, a moraine lake and a stream in $\mathrm{Hi}$ malayan glacier, Extremophiles, 15, 411-421, 2011.

Logan, G. A., Hayes, J. M., Hieshima, G. B., and Summons, R. E.: Terminal Proterozoic Reorganization of Biogeochemical Cycles, Nature, 376, 53-56, 1995.

Loisel, H., Nicolas, J. M., Deschamps, P. Y., and Frouin, R.: Seasonal and inter-annual variability of particulate organic matter in the global ocean, Geophys. Res. Lett., 29, 2196, doi:10.1029/2002g1015948, 2002.

Loucaides, S., Tyrrell, T., Achterberg, E. P., Torres, R., Nightingale, P. D., Kitidis, V., Serret, P., Woodward, M., and Robinson, C.: Biological and physical forcing of carbonate chemistry in an upwelling filament off northwest Africa: Results from a Lagrangian study, Global. Biogeochem. Cy., 26, GB3008, doi:10.1029/2011gb004216, 2012.

Luisetti, T., Turner, R. K., Bateman, I. J., Morse-Jones, S., Adams, C., and Fonseca, L.: Coastal and marine ecosystem services valuation for policy and management: Managed realignment case studies in England, Ocean. Coast. Manage., 54, 212-224, 2011.

Luo, Y. W., Friedrichs, M. A. M., Doney, S. C., Church, M. J., and Ducklow, H. W.: Oceanic heterotrophic bacterial nutrition 
by semilabile DOM as revealed by data assimilative modeling, Aquat. Microb. Ecol., 60, 273-287, 2010.

Maiti, K., Benitez-Nelson, C. R., Rii, Y., and Bidigare, R.: The influence of a mature cyclonic eddy on particle export in the lee of Hawaii, Deep-Sea Res. Pt II, 55, 1445-1460, 2008.

Mannino, A., Russ, M. E., and Hooker, S. B.: Algorithm development and validation for satellite-derived distributions of DOC and CDOM in the US Middle Atlantic Bight, J. Geophys. Res., 113, C07051, doi:10.1029/2007jc004493, 2008.

Marchant, H. J. and Scott, F. J.: Uptake of sub-micrometre particles and dissolved organic material by Antarctic choanoflagellates, Mar. Ecol.-Prog. Ser., 92, 59-64, 1993.

Mari, X.: Does ocean acidification induce an upward flux of marine aggregates?, Biogeosciences, 5, 1023-1031, doi:10.5194/bg-51023-2008, 2008.

Maritorena, S. and Siegel, D. A.: Consistent merging of satellite ocean color data sets using a bio-optical model, Remote Sens. Environ., 94, 429-440, 2005.

McFadden, K. A., Huang, J., Chu, X., Jiang, G., Kaufman, A. J., Zhou, C., Yuan, X., and Xiao, S.: Pulsed oxidation and biological evolution in the Ediacaran Doushantuo Formation, P. Natl. Acad. Sci. USA, 105, 3197-3202, 2008.

McGillicuddy Jr., D. J., Robinson, A. R., Siegel, D. A., Jannasch, H. W., Johnson, R., Dickey, T. D., McNeil, J., Michaels, A. F., and Knap, A. H.: Influence of mesoscale eddies on new production in the Sargasso Sea, Nature, 394, 263-266, 1998.

McNichol, A. P. and Aluwihare, L. I.: The power of radiocarbon in biogeochemical studies of the marine carbon cycle: insights from studies of dissolved and particulate organic carbon (DOC and POC), Chem. Rev., 107, 443-466, 2007.

Mitra, A., Flynn, K. J., Burkholder, J. M., Berge, T., Calbet, A., Raven, J. A., Granéli, E., Glibert, P. M., Hansen, P. J., Stoecker, D. K., Thingstad, F., Tillmann, U., Våge, S., Wilken, S., and Zubkov, M. V.: The role of mixotrophic protists in the biological carbon pump, Biogeosciences, 11, 995-1005, doi:10.5194/bg11-995-2014, 2014.

Moore, T. S., Mullaugh, K. M., Holyoke, R. R., Madison, A. S., Yucel, M., and Luther, G. W.: Marine Chemical Technology and Sensors for Marine Waters: Potentials and Limits, Annu. Rev. Mar. Sci., 1, 91-115, 2009.

Moran, M. A.: Genomics and metagenomics of marine prokaryotes, in: Microbial Ecology of the Oceans, edited by: Kirchman, D. L., John Wiley and Sons, Inc., Hoboken, New Jersey, 91-129, 2008.

Moran, X. A. G., Taupier-Letage, I., Vazquez-Dominguez, E., Ruiz, S., Arin, L., Raimbault, P., and Estrada, M.: Physical-biological coupling in the Algerian Basin (SW Mediterranean): Influence of mesoscale instabilities on the biomass and production of phytoplankton and bacterioplankton, Deep-Sea Res. Pt. I, 48, 405-437, 2001.

Morel, A. and Gentili, B.: A simple band ration technique to quantify the colored dissolved and detrital organic material from ocean color remotely sensed data, Remote Sens. Environ., 113, 998-1011, 2009.

Motegi, C., Tanaka, T., Piontek, J., Brussaard, C. P. D., Gattuso, J.P., and Weinbauer, M. G.: Effect of $\mathrm{CO}_{2}$ enrichment on bacterial metabolism in an Arctic fjord, Biogeosciences, 10, 3285-3296, doi:10.5194/bg-10-3285-2013, 2013.
Müren, U., Berglund, J., Samuelsson, K., and Andersson, A.: Potential effects of elevated sea-water temperature on pelagic food webs, Hydrobiologia, 545, 153-166, 2005.

Newbold, L. K., Oliver, A. E., Booth, T., Tiwari, B., DeSantis, T., Maguire, M., Andersen, G., van der Gast, C. J., and Whiteley, A. S.: The response of marine picoplankton to ocean acidification, Environ. Microbiol., 14, 2293-2307, 2012.

Ogawa, H., Amagai, Y., Koike, I., Kaiser, K., and Benner, R.: Production of refractory dissolved organic matter by bacteria, Science, 292, 917-920, 2001.

Parekh, P., Dutkiewicz, S., Follows, M. J., and Ito, T.: Atmospheric carbon dioxide in a less dusty world, Geophys. Res. Lett., 33, L03610, doi:10.1029/2005g1025098, 2006.

Park, J. T. and Uehara, T.: How bacteria consume their own exoskeletons (Turnover and recycling of cell wall peptidoglycan), Microbiol. Mol. Biol. R, 72, 211-227, 2008.

Passow, U.: Production of transparent exopolymer particles (TEP) by phyto-and bacterioplankton, Mar. Ecol.-Prog. Ser., 236, 1-12, 2002.

Passow, U.: The abiotic formation of TEP under different ocean acidification scenarios, Mar. Chem., 128, 72-80, 2012.

Passow, U. and Carlson, C. A.: The biological pump in a high $\mathrm{CO}_{2}$ world, Mar. Ecol.-Prog. Ser., 470, 249-271, 2012.

Paulino, A. I., Egge, J. K., and Larsen, A.: Effects of increased atmospheric $\mathrm{CO}_{2}$ on small and intermediate sized osmotrophs during a nutrient induced phytoplankton bloom, Biogeosciences, 5, 739-748, doi:10.5194/bg-5-739-2008, 2008.

Pedrotti, M. L., Fiorini, S., Kerros, M. E., Middelburg, J. J., and Gattuso, J. P.: Variable production of transparent exopolymeric particles by haploid and diploid life stages of coccolithophores grown under different $\mathrm{CO}_{2}$ concentrations, J. Plankton. Res., 34, 388-398, 2012.

Piontek, J., Lunau, M., Händel, N., Borchard, C., Wurst, M., and Engel, A.: Acidification increases microbial polysaccharide degradation in the ocean, Biogeosciences, 7, 1615-1624, doi:10.5194/bg-7-1615-2010, 2010.

Piontek, J., Borchard, C., Sperling, M., Schulz, K. G., Riebesell, U., and Engel, A.: Response of bacterioplankton activity in an Arctic fjord system to elevated $p \mathrm{CO}_{2}$ : results from a mesocosm perturbation study, Biogeosciences, 10, 297-314, doi:10.5194/bg-10297-2013, 2013.

Polimene, L., Allen, J. I., and Zavatarelli, M.: Model of interactions between dissolved organic carbon and bacteria in marine systems, Aquat. Microb. Ecol., 43, 127-138, 2006.

Poretsky, R. S., Sun, S., Mou, X., and Moran, M. A.: Transporter genes expressed by coastal bacterioplankton in response to dissolved organic carbon, Environ. Microbiol., 12, 616-627, 2010.

Prentice, I. C., Farquhar, G. D., Fasham, M. J. R., Goulden, M. L., Heimann, M., Jaramillo, V. J., Kheshgi, H. S., LeQuéré, C., Scholes, R. J., and Wallace, D. W. R.: The Carbon Cycle and Atmospheric Carbon Dioxide, in: Climate Change 2001: the Scientific Basis. Contributions of Working Group I to the Third Assessment Report of the Intergovernmental Panel on Climate Change, edited by: Houghton, J. T., Ding, Y., Griggs, D. J., Noguer, M., van der Linden, P. J., Dai, X., Maskell, K., and Johnson, C. A., Cambridge University Press, Cambridge, UK, 185-237, 2001.

Prowe, A. E. F., Thomas, H., Patsch, J., Kuhn, W., Bozec, Y., Schiettecatte, L. S., Borges, A. V., and de Baar, H. J. W.: Mechanisms 
controlling the air-sea $\mathrm{CO}_{2}$ flux in the North Sea, Cont. Shelf. Res., 29, 1801-1808, 2009.

Riebesell, U. and Tortell, P. D.: Effects of ocean acidification on pelagic organisms and ecosystems, in: Ocean Acidification, edited by: Gattuso, J. and Hanson, L., Oxford University Press, Oxford, 99-121, 2011.

Riebesell, U., Czerny, J., von Bröckel, K., Boxhammer, T., Büdenbender, J., Deckelnick, M., Fischer, M., Hoffmann, D., Krug, S. A., Lentz, U., Ludwig, A., Muche, R., and Schulz, K. G.: Technical Note: A mobile sea-going mesocosm system - new opportunities for ocean change research, Biogeosciences, 10, 18351847, doi:10.5194/bg-10-1835-2013, 2013.

Riemann, L. and Azam, F.: Widespread N-acetyl-D-glucosamine uptake among pelagic marine bacteria and its ecological implications, Appl. Environ. Microb., 68, 5554-5562, 2002.

Robinson, C., Poulton, A. J., Holligan, P. M., Baker, A. R., Forster, G., Gist, N., Jickells, T. D., Malin, G., Upstill-Goddard, R., Williams, R. G., Woodward, E. M. S., and Zubkov, M. V.: The Atlantic Meridional Transect (AMT) Programme: A contextual view 1995-2005, Deep-Sea Res. Pt. II, 53, 1485-1515, 2006.

Rochelle-Newall, E., Delille, B., Frankignoulle, M., Gattuso, J. P., Jacquet, S., Riebesell, U., Terbrüggen, A., and Zondervan, I.: Chromophoric dissolved organic matter in experimental mesocosms maintained under different $p \mathrm{CO}_{2}$ levels, Mar. Ecol.-Prog. Ser., 272, 25-31, 2004.

Roland, L. A., McCarthy, M. D., and Guilderson, T.: Sources of molecularly uncharacterized organic carbon in sinking particles from three ocean basins: A coupled $\Delta^{14} \mathrm{C}$ and $\delta^{13} \mathrm{C}$ approach, Mar. Chem., 111, 199-213, 2008.

Romanou, A., Romanski, J., and Gregg, W. W.: Natural ocean carbon cycle sensitivity to parameterizations of the recycling in a climate model, Biogeosciences, 11, 1137-1154, doi:10.5194/bg11-1137-2014, 2014.

Rothman, D. H., Hayes, J. M., and Summons, R. E.: Dynamics of the Neoproterozoic carbon cycle, P. Natl. Acad. Sci. USA, 100, 8124-8129, 2003.

Sathyendranath, S., Stuart, V., Nair, A., Oka, K., Nakane, T., Bouman, H., Forget, M. H., Maass, H., and Platt, T.: Carbonto-chlorophyll ratio and growth rate of phytoplankton in the sea, Mar. Ecol.-Prog. Ser., 383, 73-84, 2009.

Schrag, D. P., Higgins, J. A., Macdonald, F. A., and Johnston, D. T.: Authigenic carbonate and the history of the global carbon cycle, Science, 339, 540-543, 2013.

Schulz, K. G., Riebesell, U., Bellerby, R. G. J., Biswas, H., Meyerhöfer, M., Müller, M. N., Egge, J. K., Nejstgaard, J. C., Neill, C., Wohlers, J., and Zöllner, E.: Build-up and decline of organic matter during PeECE III, Biogeosciences, 5, 707-718, doi:10.5194/bg-5-707-2008, 2008

Sherr, E. B.: Direct Use of High Molecular-Weight Polysaccharide by Heterotrophic Flagellates, Nature, 335, 348-351, 1988.

Siegel, D. A., Maritorena, S., Nelson, N. B., Hansell, D. A., and Lorenzi-Kayser, M.: Global distribution and dynamics of colored dissolved and detrital organic materials, J. Geophys. Res., 107, 3228, doi:10.1029/2001jc000965, 2002.

Siegel, D. A., Maritorena, S., Nelson, N. B., Behrenfeld, M. J., and McClain, C. R.: Colored dissolved organic matter and its influence on the satellite-based characterization of the ocean biosphere, Geophys. Res. Lett., 32, L20605, doi:10.1029/2005gl024310, 2005.
Staats, N., Stal, L. J., and Mur, L. R.: Exopolysaccharide production by the epipelic diatom Cylindrotheca closterium: effects of nutrient conditions, J. Exp. Mar. Biol. Ecol., 249, 13-27, 2000.

Stocker, R.: Marine microbes see a sea of gradients, Science, 338, 628-633, 2012.

Stramska, M.: Particulate organic carbon in the global ocean derived from SeaWiFS ocean color, Deep-Sea Res. Pt. I, 56, 1459-1470, 2009.

Stramski, D., Reynolds, R. A., Kahru, M., and Mitchell, B. G.: Estimation of particulate organic carbon in the ocean from satellite remote sensing, Science, 285, 239-242, 1999.

Stramski, D., Reynolds, R. A., Babin, M., Kaczmarek, S., Lewis, M. R., Röttgers, R., Sciandra, A., Stramska, M., Twardowski, M. S., Franz, B. A., and Claustre, H.: Relationships between the surface concentration of particulate organic carbon and optical properties in the eastern South Pacific and eastern Atlantic Oceans, Biogeosciences, 5, 171-201, doi:10.5194/bg-5-171-2008, 2008.

Sturt, H. F., Summons, R. E., Smith, K., Elvert, M., and Hinrichs, K. U.: Intact polar membrane lipids in prokaryotes and sediments deciphered by high-performance liquid chromatography/electrospray ionization multistage mass spectrometry-new biomarkers for biogeochemistry and microbial ecology, Rapid Commun. Mass Sp., 18, 617-628, 2004.

Suzumura, M.: Phospholipids in marine environments: a review, Talanta, 66, 422-434, 2005.

Swan, B. K., Martinez-Garcia, M., Preston, C. M., Sczyrba, A., Woyke, T., Lamy, D., Reinthaler, T., Poulton, N. J., Masland, E. D. P., Gomez, M. L., Sieracki, M. E., DeLong, E. F., Herndl, G. J., and Stepanauskas, R.: Potential for Chemolithoautotrophy Among Ubiquitous Bacteria Lineages in the Dark Ocean, Science, 333, 1296-1300, 2011.

Swanson-Hysell, N. L., Rose, C. V., Calmet, C. C., Halverson, G. P., Hurtgen, M. T., and Maloof, A. C.: Cryogenian glaciation and the onset of carbon-isotope decoupling, Science, 328, 608-611, 2010.

Tang, K., Jiao, N., Liu, K., Zhang, Y., and Li, S.: Distribution and functions of TonB-dependent transporters in marine bacteria and environments: implications for dissolved organic matter utilization, Plos One, 7, e41204, doi:10.1371/journal.pone.0041204, 2012.

Tarran, G. A., Zubkov, M. V., Sleigh, M. A., Burkill, P. H., and Yallop, M.: Microbial community structure and standing stocks in the NE Atlantic in June and July of 1996, Deep-Sea Res. Pt. II, 48, 963-985, 2001.

Taylor, P. G. and Townsend, A. R.: Stoichiometric control of organic carbon-nitrate relationships from soils to the sea, Nature, 464, 1178-1181, 2010.

Teira, E., Pazo, M. J., Serret, P., and Fernandez, E.: Dissolved organic carbon production by microbial populations in the Atlantic Ocean, Limnol. Oceanogr., 46, 1370-1377, 2001.

Thomas, H., Ittekkot, V., Osterroht, C., and Schneider, B.: Preferential recycling of nutrients - the ocean's way to increase new production and to pass nutrient limitation?, Limnol. Oceanogr. 44, 1999-2004, 1999.

Thomas, H., Bozec, Y., Elkalay, K., and de Baar, H. J. W.: Enhanced open ocean storage of $\mathrm{CO}_{2}$ from shelf sea pumping, Science, 304, 1005-1008, 2004.

Tortell, P. D., DiTullio, G. R., Sigman, D. M., and Morel, F. M. M.: $\mathrm{CO}_{2}$ effects on taxonomic composition and nutrient utilization 
in an Equatorial Pacific phytoplankton assemblage, Mar. Ecol.Prog. Ser., 236, 37-43, 2002.

Tsunogai, S. and Noriki, S.: Particulate Fluxes of Carbonate and Organic-Carbon in the Ocean - Is the Marine Biological-Activity Working as a Sink of the Atmospheric Carbon, Tellus B, 43, 256266, 1991.

Uitz, J., Claustre, H., Gentili, B., and Stramski, D.: Phytoplankton class-specific primary production in the world's oceans: Seasonal and interannual variability from satellite observations, Global. Biogeochem. Cy., 24, GB3016, doi:10.1029/2009gb003680, 2010.

Ullman, R., Bilbao-Bastida, V., and Grimsditch, G.: Including Blue Carbon in climate market mechanisms, Ocean. Coast. Manage., 83, 15-18, 2013.

van Haren, H., Millot, C., and Taupier-Letage, I.: Fast deep sinking in Mediterranean eddies, Geophys. Res. Lett., 33, L04606, doi:10.1029/2005g1025367, 2006.

Volk, T. and Hoffert, M. I.: Ocean carbon pumps: analysis of relative strength and efficiencies of in ocean-driven circulation atmospheric $\mathrm{CO}_{2}$ changes, in: The carbon cycle and atmospheric $\mathrm{CO}_{2}$ : Natural variation Archean to Present, edited by: Sundquist, E. T. and Broecker, W. S., AGU Monograph 32, American Geophysical Union, Washington, DC, 99-110, 1985.

White, A. E., Watkins-Brandt, K. S., Engle, M. A., Burkhardt, B., and Paytan, A.: Characterization of the rate and temperature sensitivities of bacterial remineralization of dissolved organic phosphorus compounds by natural populations, Front Microbiol., 3, 276, doi:10.3389/fmicb.2012.00276, 2012.

White, D. C., Davis, W. M., Nickels, J. S., King, J. D., and Bobbie, R. J.: Determination of the sedimentary microbial biomass by extractible lipid phosphate, Oecologia, 40, 51-62, 1979.
White, D. C., Flemming, C. A., Leung, K. T., and Macnaughton, S. J.: In situ microbial ecology for quantitative appraisal, monitoring, and risk assessment of pollution remediation in soils, the subsurface, the rhizosphere and in biofilms, J. Microbiol. Meth., 32, 93-105, 1998.

Wieder, W. R., Bonan, G. B., and Allison, S. D.: Global soil carbon projections are improved by modelling microbial processes, Nat. Clim. Chang., 3, 909-912, 2013.

Wohlers-Zöllner, J., Biermann, A., Engel, A., Dörge, P., Lewandowska, A. M., von Scheibner, M., and Riebesell, U.: Effects of rising temperature on pelagic biogeochemistry in mesocosm systems: a comparative analysis of the AQUASHIFT Kiel experiments, Mar. Biol., 159, 2503-2518, 2012.

Zhang, C. L., Li, Y., Wall, J. D., Larsen, L., Sassen, R., Huang, Y., Wang, Y., Peacock, A., White, D. C., Horita, J., and Cole, D. R.: Lipid and carbon isotopic evidence of methane-oxidizing and sulfate-reducing bacteria in association with gas hydrates from the Gulf of Mexico, Geology, 30, 239-242, 2002.

Zhang, R., Xia, X., Lau, S. C. K., Motegi, C., Weinbauer, M. G., and Jiao, N.: Response of bacterioplankton community structure to an artificial gradient of $p \mathrm{CO}_{2}$ in the Arctic Ocean, Biogeosciences, 10, 3679-3689, doi:10.5194/bg-10-3679-2013, 2013.

Ziervogel, B., Dhaksnamoorthy, B., Blachowicz, L., and Roux, B.: Antibiotic Binding and Dynamics within the OmpF Channel Allow Transfer Across the Bacterial Outer Membrane, Biophys. J., 100, 244-244, 2011.

Zubkov, M. V. and Tarran, G. A.: High bacterivory by the smallest phytoplankton in the North Atlantic Ocean, Nature, 455, 224$226,2008$. 